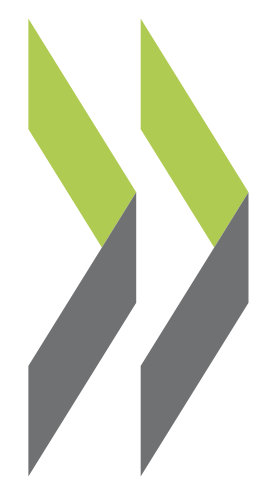

OECD Economics Department Working Papers No. 1570

Effects of tax-benefit policies on the income distribution and work incentives in Estonia

\section{Alari Paulus,}

Caroline Klein 


\section{ECONOMICS DEPARTMENT}

\section{EFFECTS OF TAX-BENEFIT POLICIES ON THE INCOME DISTRIBUTION AND WORK INCENTIVES IN ESTONIA}

\section{ECONOMICS DEPARTMENT WORKING PAPERS No. 1570}

\section{By Alari Paulus and Caroline Klein}

OECD Working Papers should not be reported as representing the official views of the OECD or of its member countries. The opinions expressed and arguments employed are those of the authors.

Authorised for publication by Isabell Koske, Deputy Director of Country Studies Branch, Economics Department.

All Economics Department Working Papers are available at www.oecd.org/eco/workingpapers.

JT03452083 
OECD Working Papers should not be reported as representing the official views of the OECD or of its member countries. The opinions expressed and arguments employed are those of the author(s).

Working Papers describe preliminary results or research in progress by the author(s) and are published to stimulate discussion on a broad range of issues on which the OECD works.

Comments on Working Papers are welcomed, and may be sent to OECD Economics Department, 2 rue André Pascal, 75775 Paris Cedex 16, France, or by e-mail to eco.contact@oecd.org.

All Economics Department Working Papers are available at www.oecd.org/eco/workingpapers.

This document and any map included herein are without prejudice to the status of or sovereignty over any territory, to the delimitation of international frontiers and boundaries and to the name of any territory, city or area.

The statistical data for Israel are supplied by and under the responsibility of the relevant Israeli authorities. The use of such data by the OECD is without prejudice to the status of the Golan Heights, East Jerusalem and Israeli settlements in the West Bank under the terms of international law.

\section{(C) OECD (2019)}

You can copy, download or print OECD content for your own use, and you can include excerpts from OECD publications, databases and multimedia products in your own documents, presentations, blogs, websites and teaching materials, provided that suitable acknowledgment of OECD as source and copyright owner is given. All requests for commercial use and translation rights should be submitted to rights@oecd.org 


\section{ABSTRACT/RÉSUMÉ}

\section{Effects of tax-benefit policies on the income distribution and work incentives in Estonia}

The paper studies the impact of tax-benefit policies on the distribution of household incomes and work incentives in Estonia. It makes use of microsimulation modelling approach and applies the EU taxbenefit model EUROMOD to quantify the first-order effects of policy changes in 2016-2018 and of a range of alternative policy scenarios aimed at increasing the adequacy of social benefits. According to the simulations, 2016-2017 policies increased household incomes relative to inflation and were both poverty and inequality reducing. Alternative policy scenarios indicate that, among the considered options, increasing the generosity of the subsistence benefit and relaxing its means test by halving the withdrawal rate (currently at 100\%), would have the highest first-order impact for a given fiscal cost. However, these measures would also weaken work incentives, which points to a conventional equity-efficiency trade-off. Other simulations demonstrate some scope for improving work incentives at low and middle-income levels together with modest reductions in poverty and inequality.

This Working Paper relates to the 2017 OECD Economic Survey of Estonia (http://www.oecd.org/economy/estonia-economic-snapshot/)

JEL codes: D31, H23, $I 38$

Keywords: tax-benefit policies, income distribution, work incentives, Estonia

\section{Effets des politiques fiscales et sociales sur la répartition des revenus et les incitations au travail en Estonie}

Le document de travail étudie l'impact des politiques fiscales et sociales sur la répartition des revenus des ménages et les incitations au travail en Estonie. Il utilise une approche de modélisation par microsimulation et le modèle EUROMOD pour quantifier les effets de premier ordre des changements de politique entre 2016 et 2018 et d'une série de scénarios de politiques alternatives visant à accroître l'adéquation des avantages sociaux. D'après les simulations, les politiques de 2016-17 ont augmenté les revenus des ménages par rapport à l'inflation et réduit à la fois la pauvreté et les inégalités. D'autres scénarios de politiques indiquent que parmi les options envisagées, augmenter la générosité de l'indemnité de subsistance et assouplir son critère de ressources en réduisant de moitié le taux de retrait (actuellement à 100\%) aurait l'impact direct le plus important pour un coût budgétaire donné. Cependant, ces mesures affaibliraient également les incitations au travail, ce qui soulève le compromis classique entre efficacité et équité. D'autres simulations montrent qu'il est possible d'améliorer les incitations au travail pour des niveaux de revenu faible et moyen tout en réduisant modestement la pauvreté et les inégalités.

Ce Document de travail se rapporte à l'Étude économique de l'OCDE de l'Estonie 2017 (http://www.oecd.org/fr/economie/estonie-en-un-coup-d-oeil/)

Classification JEL : D31, H23, I38

Mots clefs : politique fiscale et sociale, répartition du revenu, incitations au travail, Estonie 


\title{
Effects of tax-benefit policies on the income distribution and work incentives in Estonia
}

\author{
by Alari Paulus and Caroline Klein ${ }^{1}$
}

1. Despite recent significant improvements since the global financial crisis, poverty and inequality remain major challenges in Estonia. More than one out five persons was at risk of poverty in 2015 and income inequality - measured by the Gini coefficient - was the tenth highest in the OECD. High inequality partly stemmed from the low redistributive impact of transfers and taxes, well below most OECD countries (Figure 1; Causa and Hermansen, 2017). International comparisons suggest there is room for making social support more effective at reducing poverty and providing income support to jobless people in Estonia, notably by raising the coverage and the generosity of social programmes (OECD, 2017; OECD, 2012).

Figure 1. Redistributive impact of the tax and benefit systems in the OECD

Percentage reduction of market income inequality due to taxes and transfers ${ }^{1}$, working-age population, 2015 or latest available year ${ }^{2}$

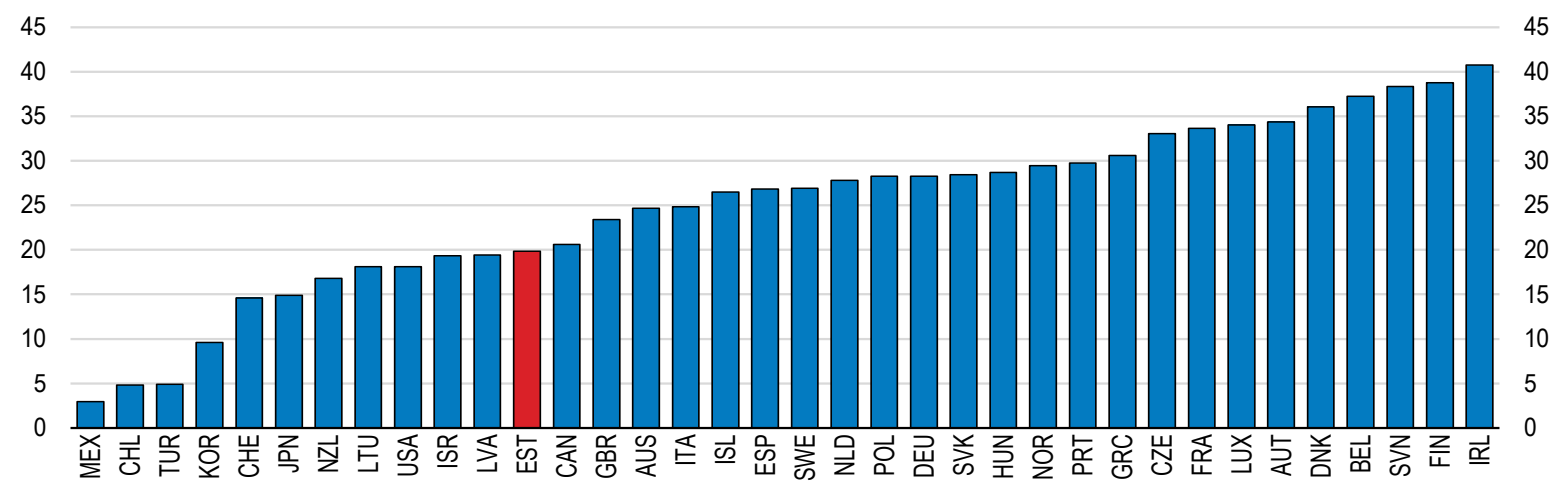

1. Redistribution is defined as the difference between market income and disposable income inequality (inequality measured using the Gini coefficient), expressed as a percentage of market income inequality. Market incomes are net of taxes in Hungary, Mexico and Turkey.

2. Latest available data refer to 2015 for Chile, Finland, Israel, Korea, Mexico, the Netherlands, the United Kingdom, and the United States; to 2012 for Japan; and to 2014 for all other countries.

Source: OECD Income Distribution database (IDD), September 2017.

1. Alari Paulus is research fellow in the Institute for Social \& Economic Research (ISER) at the University of Essex and senior analyst in PRAXIS Centre for Policy Studies. Caroline Klein is senior economist in the OECD Economics Department. The authors would like to thank Märt Masso, Mikkel Hermansen, and Olga Rastrigina for their constructive comments. The authors alone are responsible for the analysis reported here. Special thanks are due to Corinne Chanteloup for statistical assistance and Sylvie Ricordeau for editorial support. 
Reinforcing social protection is of paramount importance in small open economies like Estonia. High vulnerability to external shocks combined with weak income security reduces the resilience of the economy. The labour market flexibility, demonstrated by strong cyclical fluctuations in employment rates during the global financial crisis, implies higher risk of unemployment in times of recession. The low coverage of unemployment schemes and the low level of social benefits induce high income losses for households in case of unemployment. The absence of adequate insurance mechanisms and social safety net is thus likely to magnify the macroeconomic impact of negative external shocks. Economic literature also shows it might reduce incentives to take up formal jobs (OECD, 2008 ) and the quality of matching on the labour market, as job seekers can devote less time to find a job that match their competences (Wulfgram and Fervers, 2013; Tatsiramos, 2009).

At the same time, increasing benefit generosity might have a negative impact on labour participation by reducing the gain of taking up a job, in particular for low-wage earners. Making the most of available but scarce labour resources in Estonia is critical as active population declines and labour market participation and employment rates have reached historically highs. Thus, reforms should aim at maintaining strong work incentives. Against this background this paper discusses potential directions for reforming the tax and benefit system in Estonia.

The paper presents simulations of actual and hypothetical tax and benefit reforms in Estonia, illustrating the impact of a range of measures on poverty, inequality and work incentives, following similar work on Lithuania (Navicke et al., 2016).

- The first contribution of this paper is to evaluate the impact of existing policy measures on income distribution and work incentives. Reducing inequality in the Estonian society and fighting poverty are increasingly high in the political agenda. Measures dedicated to these purposes include increases in the level of social assistance benefits and pension allowances.

- The second contribution of the paper is to present scenarios of alternative measures that could help improving effectiveness of the benefits system, with a focus on unemployment and social assistance, whose coverage and adequacy appear to be below the OECD average.

The main findings of the paper are the following:

- Among the considered options, increasing the generosity of social assistance (i.e. the level of subsistence benefits) is found, as expected, to be the most effective way to reduce poverty and income inequality in the short run. However, such measures would weaken work incentives the most, which points to a conventional equityefficiency trade-off.

- Combining an increase in the generosity of subsistence benefits with a gradual withdrawal of benefits as work income increases, either by relaxing its means-test by partially exempting earnings or lowering the withdrawal rate (currently at $100 \%$ ), limits the potential negative impact on labour supply and the fiscal cost of the measure.

- The simulations of the 2018 income tax reform demonstrate some scope for improving work incentives at low and middle-income levels together with modest reductions in poverty and inequality. The cost of the reform appears to be relatively 
high, but the poverty-reducing impact is likely to be underestimated given positive second-round effects expected from higher labour supply.

The paper first provides a brief assessment of the redistributive impact of the Estonian tax and benefit system. In a second section, it exposes the methodology used to run microsimulations. It then presents the simulations, starting with past policy measures, then alternative policy scenarios. Finally, in a fourth section, the paper discusses the relative effectiveness in reducing poverty of all measures, both relative to their fiscal cost and to their impact on work incentives.

\section{Redistributive effects of the tax and benefit system}

\section{Adequacy and targeting of social programmes}

Poverty and income inequality in Estonia are among the tenth highest among OECD countries. A considerable proportion of the population is at risk of poverty $(22 \%$ of the population lived with less than $60 \%$ of the median income in 2016), with risks significantly higher for the unemployed, disabled and low educated. Poverty rates are relatively high for lone parents and families with three and more children. The old-aged are also more exposed, not least due to the relatively low level of pensions.

The redistributive effects of the tax and benefit system remains well below the OECD average (see Figure 1). Despite the high level of relative poverty, the level of spending allocated to protection of the most vulnerable is low. Government spending on social protection accounted for 17.7\% of GDP in 2015 (vs. 19\% on average in the OECD and around $29 \%$ in the Nordics). A relatively large share of social spending was directed to family benefits, while expenditure on social exclusion lagged behind (Table 1, see Annex 1 for details on out-of-work benefits in Estonia).

Table 1. Breakdown of social spending

$\%$ of total social protection spending, 2015

\begin{tabular}{|c|c|c|c|c|c|c|c|c|}
\hline & $\begin{array}{l}\text { Sickness and } \\
\text { disability }\end{array}$ & Old age & Survivors & $\begin{array}{c}\text { Family and } \\
\text { children }\end{array}$ & Unemployment & Housing & $\begin{array}{c}\text { Social } \\
\text { exclusion }\end{array}$ & Other \\
\hline Estonia & 16.4 & 54.5 & 0.5 & 17.9 & 8.3 & 0.2 & 1.0 & 1.2 \\
\hline Nordics $^{2}$ & 18.4 & 46.3 & 1.5 & 14.6 & 9.4 & 2.1 & 6.0 & 1.6 \\
\hline $\mathrm{OECD}^{3}$ & 15.8 & 51.3 & 6.3 & 11.2 & 7.4 & 2.3 & 3.9 & 1.9 \\
\hline
\end{tabular}

1. Unweighted average of Czech Republic, Hungary, Latvia, Lithuania, Poland, Slovak Republic, and Slovenia.

2. Unweighted average of Denmark, Finland, and Sweden.

3. Unweighted average of available OECD countries.

Source: OECD National Accounts database.

Targeting of social programmes is poor as means-tested programmes account for a low share in total social spending. As a result, low-income households receive a relatively small part of transfers: around $8 \%$ of transfers were allocated to the $10 \%$ poorest in 2014 (OECD, 2017). In addition, suggestive evidence on the take up of social assistance benefits points 
to relatively high coverage gaps: as much as $50 \%$ of the subsistence benefits and $70-80 \%$ of the needs-based family benefits may be left unclaimed. ${ }^{2}$

Absolute poverty - the share of those who live with less than around EUR 200 per month has declined from $8 \%$ in 2012 to $4 \%$ in 2015 , but relative poverty, measured as the share of population earning less than $60 \%$ of the median equivalised household disposable income, has not followed the same pattern. A series of measures aiming at raising the level of some social benefits including a substantial re-evaluation of subsistence benefits in 2016 (from EUR 90 to EUR 130 per month), partly compensated the absence of indexation of transfers whose value tended to depreciate in real terms, thereby increasing the income gap between those in employment and those out of work. While these measures might reduce poverty risks vis-a-vis a no policy change scenario, they are unlikely to bring the redistributive impact of the tax and benefit system up to OECD standards and reduce income inequality.

\section{Disincentives to work}

2. A series of indicators can be used to evaluate work incentives across the income distribution and by household types (Box 1). In this paper, work incentives at the intensive margin, i.e. the gains to increase work intensity, are estimated by the marginal effective tax rate (METR). This measure is relevant for those currently in work. The participation tax rate (PTR) is used to estimate the gains of taking up a job (incentives at the extensive margin) for those currently out of work.

\section{Box 1. Measuring work incentives}

- Marginal effective tax rates (METR) measure work incentives at the intensive margin of the labour supply, i.e. financial gains of a marginal increase in work intensity. They measure how much of the income gain related to a 3\% increase in individual gross earnings (roughly equivalent to working one extra hour per week) is taxed away due the tax and benefit system. A high METR reflects lower incentives to increase working time.

$$
\operatorname{METR}_{\mathrm{k}}=1-\left[y_{b}-y_{a}\right] / \Delta x
$$

with $y_{b}$ the equivalised household disposable income after the increase in work intensity, $y_{a}$ the equivalised household disposable income before the increase in work intensity and $\Delta x$ the change in gross earnings of the person.

- Participation tax rates (PTR) measure work incentives at the extensive margin of labour supply, i.e. financial gains of taking up a job when unemployed. PTR are calculated on the working age population currently out of work, not in education, not in receipt of public pensions or maternity benefits, for a range of assumed wage levels $(33 \%, 50 \%, 67 \%, 100 \%$ and $150 \%$ of the average gross wage) when working full-time. They measure how much of the income gain related to taking up a job paid at a given wage level is taxed away due to the tax and benefit system. A high PTR reflects relatively low work incentives.

2. In absence of official estimates of benefit take-up rates, the number of actual recipients are compared with estimates of eligible population for each benefit separately, measured with EUROMOD simulations (Masso et al., 2017, 2018). Some of the differences are likely to reflect data measurement and simulation accuracy though. 


$$
\mathrm{PTR}_{\mathrm{k}}=1-\left[y_{\text {in }}-y_{\text {out }}\right] / \Delta x
$$

with $y_{\text {in }}$ the equivalised household disposable income when the person is employed, $y_{\text {out }}$ the equivalised household disposable income when the person is out of work and $\Delta x$ the change in gross earnings of the person when employed.

Marginal effective tax rates (METR) for working population have been stable at around $23 \%$ on average over the last five years (2013-2017). METR mostly reflect personal income taxes as employee social security contributions and means-tested benefits are relatively low. While METR are twice higher in the first income decile group than the average because of means-tested benefits, the distribution of METR is quite compressed for all other decile groups due to the flat income tax rate $(20 \%)$ and the relatively low level of non-taxable income (EUR 180 per month in 2017) (Figure 2, Panel A). Marginal effective tax rates are higher for one-earner couples with children compared with other household types due to the receipt of means-tested benefits (Figure 2, Panel B). Estimates from the OECD Tax-benefit model indicate that METR were close or below the OECD average at low wage levels for most types of households in 2016.

Figure 2. Average marginal effective tax rates

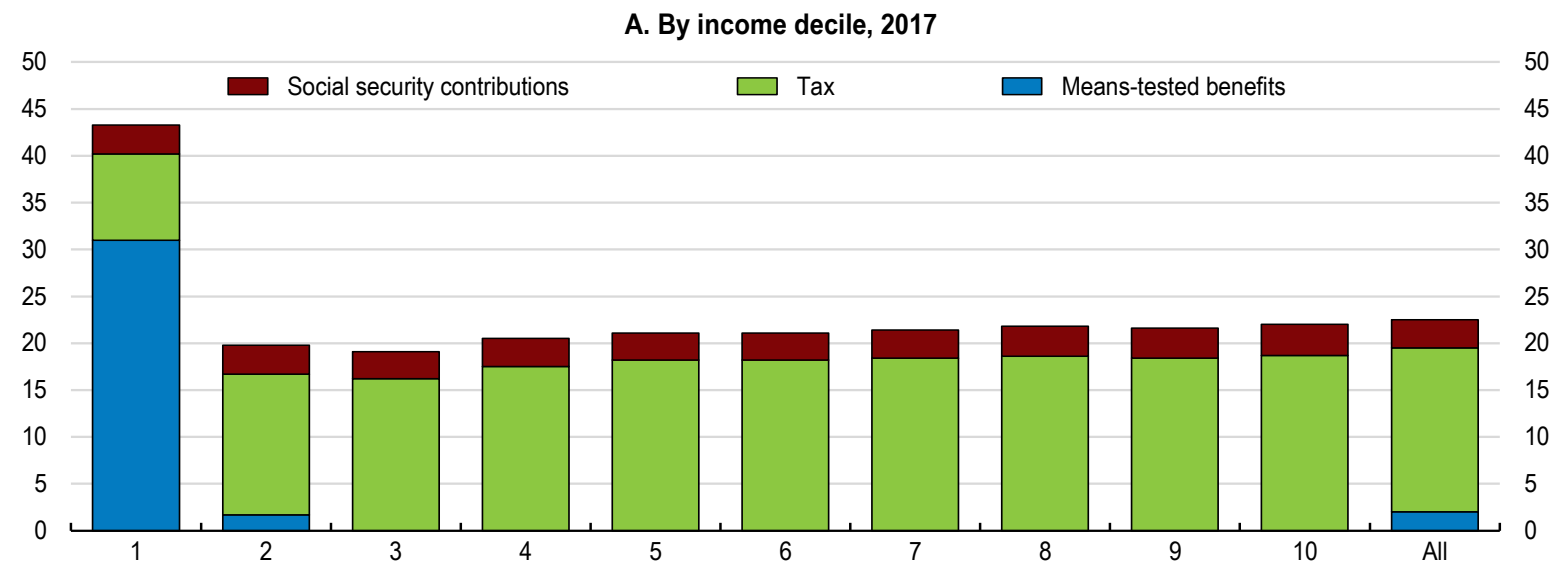

B. By household type, 2017

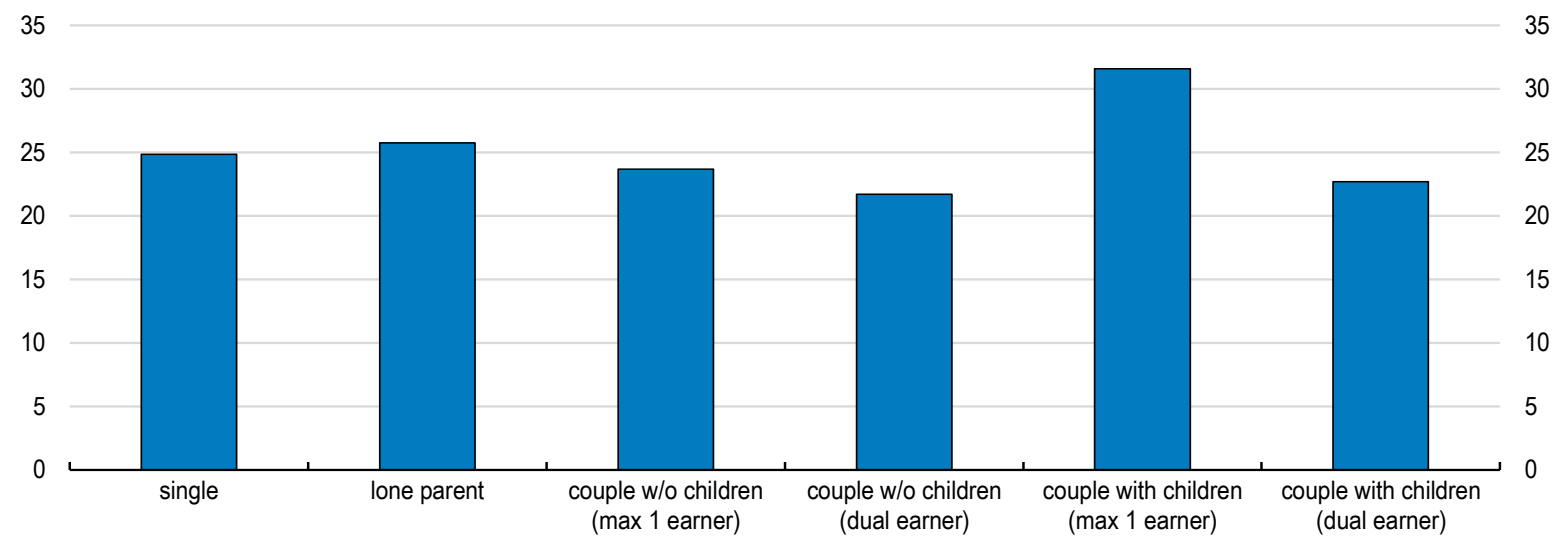

Note: Children refer to persons younger than 18 and other household types (e.g. parents with children older than 18 or multigenerational families) are not included.

Source: Authors' calculations based on EUROMOD and SILC 
Participation tax rates (PTR) for individuals out of work, indicators of incentives to work at the extensive margin, have increased somewhat since 2013, reflecting rises in meanstested benefits. Particularly high at low wage levels, participation tax rates point to an average taxation of 33\% for taking up a low-paid job (Figure 3, Panel A). Like for METR, the tax burden captured by the PTR arises mainly from the personal income tax. According to the OECD Tax-Benefit model, PTR were particularly high and above the OECD average for lone parents and one-earner couples taking up jobs paid at the minimum wage in 2016.

Figure 3. Average participation tax rates for those out of work

A. By wage level, $\%$

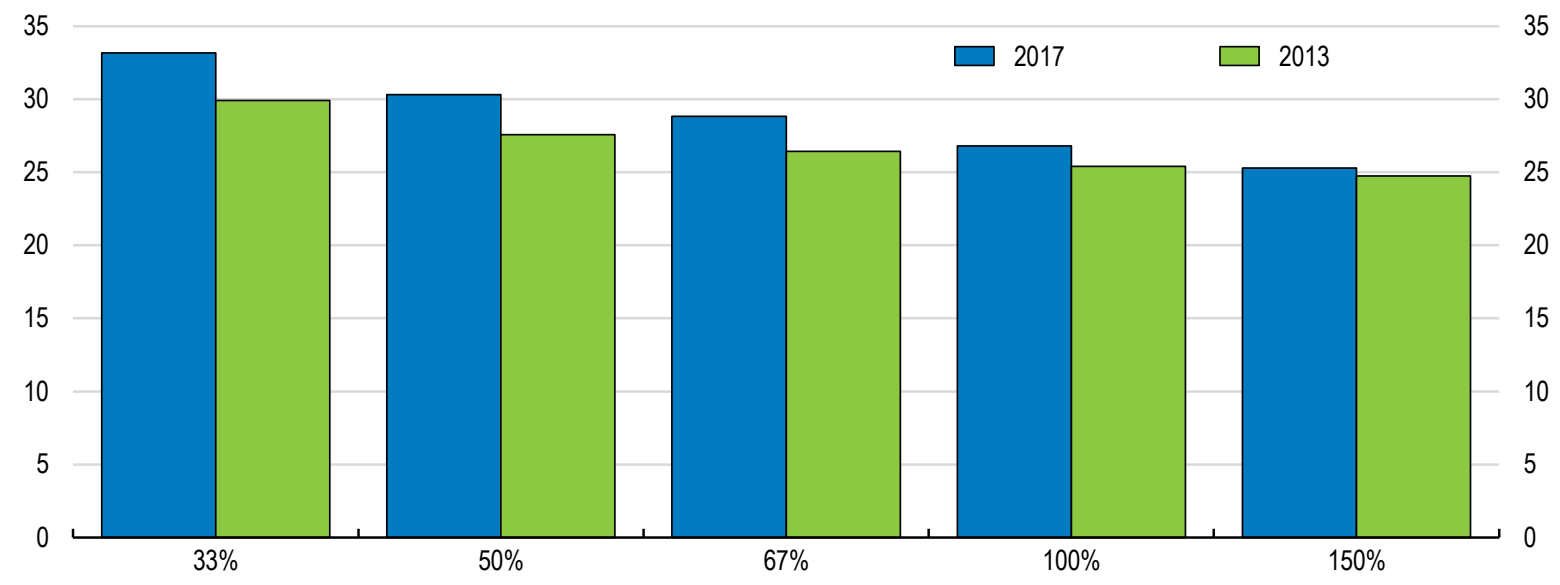

B. By household type and wage level, \%, 2017

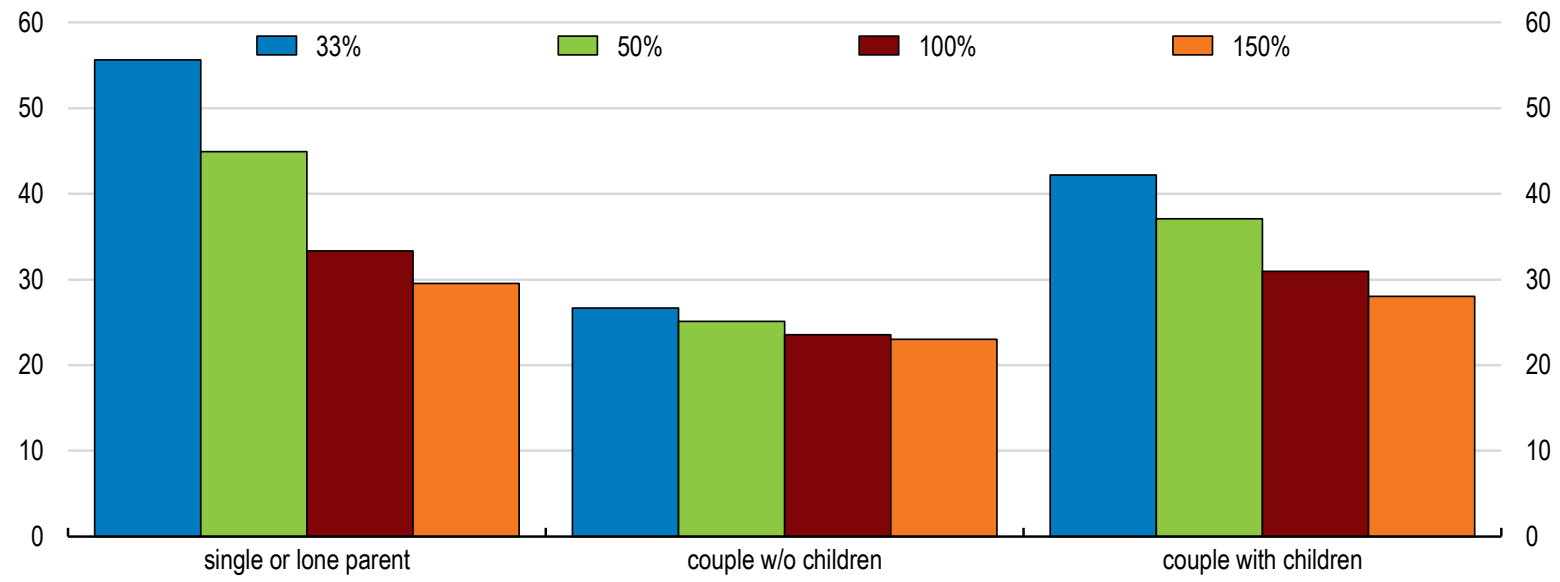

Note: Children refer to persons younger than 18 and other household types (e.g. parents with children older than 18 or multi-generational families) are not included.

Source: Authors' calculations based on EUROMOD and SILC.

Household composition has a major impact on the taxation of returning to work at lower wage levels. PTR are particularly high for singles and lone parents compared to couples, especially when the hiring wage is low. More than half of their income gained by taking up a job paid at $33 \%$ of the average wage is taxed away, due to the removal of means-tested 
benefits (Figure 3, Panel B). ${ }^{3}$ Disincentives to work are lower for couples as they receive less mean-tested benefits on average. Also, family benefits are not means-tested and thus not withdrawn when income increases. These results indicate that policy makers should give particular attention to the design of means-tested benefits and reduce work disincentives already high for low wage earners, especially for those living alone.

\section{Methodology}

The EUROMOD tax-benefit microsimulation model (Sutherland and Figari, 2013) is used to estimate the effects of policy measures on household disposable income, and thereby on work incentives, poverty, and inequality. The main functionality of EUROMOD is to calculate household disposable income for a representative sample of households using household and individual micro-data and applying coded rules for tax and benefit instruments.

The model simulates the impact of direct taxes, social insurance contributions and a large number of benefits, including unemployment benefits and social assistance, at the micro level (Masso et al., 2017). Data limitations do not generally allow simulation of contributory benefits, wealth and property taxes, and these are taken directly from the underlying survey data. The model is estimated and calibrated with micro-data for Estonia from the 2015 European Union Survey of Income and Living Conditions (EU-SILC) complemented with additional variables from the Estonian Social Survey. ${ }^{4}$

The results of the model should be interpreted with caution as they do not take into account potential behavioural effects of the simulated policy measures, for instance changes in labour supply. The model is static and intended for estimating the first-order effects of taxbenefit policy changes. The simulated reforms, by changing work incentives, will modify labour supply, employment, and subsequent income. The impact of these changes and second round effects are likely to be large in particular on poverty and public finances, but are out of the scope of this paper.

\section{Impact of selected reforms}

\section{Tax and benefit policy changes between 2015 and 2017}

This section presents the simulations of the impact of tax and benefit policy changes implemented between July 2015 and June 2017, notably the increases in the subsistence benefit from EUR 90 to EUR 130 per month and the increase in income tax allowances (Box 2). ${ }^{5}$

3. While the measures are not fully comparable, participation tax rates calculated with the OECD Tax and Benefit Model follow a similar pattern. Singles face higher disincentives to work than two-earner couples with or without children when unemployed or receiving social assistance.

4. The results presented here are based on EUROMOD version H0.34. EUROMOD is maintained, developed and managed by the Institute for Social and Economic Research (ISER) at the University of Essex, in collaboration with national teams from the EU member states. We are indebted to the many people who have contributed to the development of EUROMOD. The process of extending and updating EUROMOD is financially supported by the European Union Programme for Employment and Social Innovation 'Easi' (20142020). We use microdata from the EU Statistics on Incomes and Living Conditions (EU-SILC) made available by Eurostat (59/2013-EU-SILC-LFS), extended with selected variables from the Estonian SILC database (Eesti Sotsiaaluuring) provided for the purpose of simulations in EUROMOD by Statistics Estonia.

5. In line with the EUROMOD convention, policies are modelled as of 30th of June of the modelled year. 
Box 2. Main policy changes included in the simulations for 2016-2017

\section{Public pensions and social benefits}

- Maximum amount of subsistence benefit (excl. compensation for housing costs) increased from EUR 90 per month to EUR 130 in 2016.

- Introduction of a pensioner's living alone allowance in 2017.

- Statutory indexation rate for public pensions: 5.7\% in 2016 and 5.1\% in 2017 .

- Increase in the child allowance for first/second child from EUR 45 per month to EUR 50 in 2016.

- Reference average earnings for unemployment insurance benefit increased from EUR 25.78 per day to EUR 28.04 in 2016 and EUR 29.98 in 2017.

- Unemployment allowance increased from EUR 4.01 per day to EUR 4.41 in 2016 and EUR 4.86 in 2017.

\section{Income tax and social insurance contributions}

- Increase of the income tax allowance from EUR 1848 per year to EUR 2040 in 2016 and EUR 2160 in 2017.

- Increase of the income tax allowance for pension income from EUR 2640 per year to EUR 2700 in 2016 and EUR 2832 in 2017.

- Introduction of the upper limit on deductible mortgage interest payments (EUR 300 per year) in 2017.

To simulate the impact of policy changes between 2015 and 2017, the policy parameters of respective years are applied to the 2015 population data and resulting income distributions compared. Any variable of interest, $I$ (e.g. poverty indexes, Box 3), is calculated on the basis of household disposable incomes $y_{k}\left(c, x, m_{k}\right)$ by applying tax-benefit rules $k$ to household characteristics $c$ and market incomes $x$, taking policy parameters with monetary values $m_{k}$ (e.g. income limits, benefit amounts, tax thresholds) as further arguments. In a comparison of the counterfactual and actual income distribution for 2015 (baseline), therefore only tax-benefit policies vary, while population socio-demographic characteristics and market incomes are kept constant, allowing us to obtain the pure policy effect. To measure income components consistently in 2015 units, 2017 policy parameters are adjusted to reflect price and/or income changes in this period. The estimate of policy effects could then take the following form:

$$
\Delta I^{P}=I\left[y_{B}\left(c_{A}, x_{A}, p^{-1} m_{B}\right)\right]-I\left[y_{A}\left(c_{A}, x_{A}, m_{A}\right)\right]
$$

where $p$ denotes the benchmark indexation factor, subscript $A$ refers to 2015 and subscript $B$ to 2017. This kind of decomposition is path-dependent and there can be multiple permutations, which is overcome by calculating all possible combinations and averaging them (the so-called Shorrocks-Shapley approach). We follow a refined version of Bargain and Callan (2010) decomposition, suggested in Paulus and Tasseva (2018). 


\section{Box 3. Indicators for poverty and inequality}

\section{Poverty}

Two indices are used to measure poverty (Foster et al., 1984):

- The relative poverty rate shows the proportion of people with equivalised household disposable income below the poverty line $(60 \%$ of the median equivalised household disposable income).

- The poverty gap measures the average shortfall from the poverty line expressed as a percentage of the poverty line (across the whole population).

\section{Inequality}

- The Gini coefficient is based on the comparison of cumulative proportions of the population (ordered by their equivalised household disposable income) against cumulative proportions of income they receive. It ranges between 0 in the case of perfect equality and 1 in the case of perfect inequality.

The choice of the indexation factor, $p$, can have a significant impact on results (Paulus et al., 2019). Like in De Agostini et al. (2015, 2016), and Paulus and Tasseva (2018), changes in consumer price indices (CPI) and nominal growth in average market incomes (MII) are used to index policy parameters in the counterfactual scenario.

- A CPI-based benchmark allows measuring the effect of policy changes on household incomes in real terms. If in practice, monetary tax-benefit parameters were adjusted by prices (keeping their real value constant), and there were no structural changes whatsoever, then this benchmark would show policy changes being neutral towards the income distribution. However, at times when real market incomes were growing, such policies would lead to households who are more reliant on benefit or pension income to fall behind those relying mainly on market incomes. Inequality would likely increase and the government's fiscal balance would improve as a result of the so-called fiscal drag (Immervoll, 2005; Paulus et al., 2019).

- The MII-based benchmark captures the fiscal drag by measuring income changes relative to average market incomes. With this benchmark, only policies which maintain the relative income position of benefit recipients and wage earners are neutral on public finances and on the income distribution. On the other hand, such a benchmark is pro-cyclical by nature and may not adequately reflect changes in household well-being, leading us to generally prefer the CPI-based benchmark for the simulations.

- In practice, most of the policy parameters with monetary values (income limits, benefit amounts, tax thresholds) are generally not adjusted on a regular basis in Estonia. Inflation has been rather low in 2015-2017, while market incomes have increased fast.

The simulations show the 2015-2017 tax-benefit policy changes (with parameters deflated by CPI) increased incomes of the poorest (Figure 4). Overall, disposable income of households in the lowest decile group increased by around $10 \%$ vs. $1.8 \%$ in the total income 
distribution (Figure 4, Panel A). At the same time, the gain relative to market income was moderate for the bottom decile group (3.1\%; Figure 4, Panel B), and negative and regressive for the rest of the income distribution. Policies since mid-2015 were on average more favourable than price developments but lagged slightly behind average increases in market incomes (in particular nominal increases in public pensions). Policy developments between 2015 and 2017 thus resulted in a small fiscal drag and an improvement in government's net fiscal position (Table 2).

Table 2. Aggregate fiscal effects of policy changes

\begin{tabular}{lrcc}
\hline & $\begin{array}{c}\text { 2015 baseline } \\
\text { EUR million }\end{array}$ & $\begin{array}{c}\text { Impact in 2017 } \\
\text { CPI index } \\
\text { (baseline benchmark) }\end{array}$ & $\begin{array}{c}\text { MIl index } \\
\text { (alternative benchmark) }\end{array}$ \\
\hline Market income & $8,223.2$ & 0.0 & 0.0 \\
Public pensions & $1,569.8$ & 104.6 & -34.5 \\
Non means-tested benefits & 560.7 & 33.6 & -13.1 \\
Means-tested benefits & 40.9 & 30.8 & 21.2 \\
Workers SIC & 277.1 & 1.7 & 0.8 \\
Income taxes & $1,365.8$ & -2.4 & 13.5 \\
\hline Total budget impact & $\mathbf{8 , 7 5 1 . 8}$ & 169.6 & -40.6 \\
\hline
\end{tabular}

Note: The assessment covers fiscal measures with a direct effect on household disposable incomes. For example, changes in employer SIC and indirect taxes are outside the scope of the analysis.

Source: Authors' calculations based on EUROMOD and SILC.

In the lower end of the income distribution, most of the increase is coming from meanstested benefits (in particular increases in the subsistence benefits). In other parts of the income distribution, most of the income gain comes from increases in public pensions, which have nevertheless been lower than growth in market incomes on average.

Overall, the tax and benefit reforms are found to reduce relative poverty and inequality (Figure 5, Panel A), respectively measured as the share of population earning less than $60 \%$ of the median equivalised household disposable income and by the Gini coefficient (see Box 3). ${ }^{6}$ The poverty reducing effect is more pronounced for the elderly than on the working age population as is the policy impact on disposable income (Figure 5, Panel B and C). Nevertheless, impact on the poverty gap is small for this group, as pensioners are mostly situated close to the poverty line, making their poverty headcount measure sensitive to small changes in incomes. Single households and lone parents are those who benefitted the most from changes in the tax and benefit model (Figure 5, Panel C).

6. As discussed above, the CPI indexation is preferred to MII indexation for the analysis of simulation results. With MII indexation, 2016-17 policy measures do not have a significant impact on poverty and inequality. 


\section{Figure 4. $\quad$ Estimated effects of recent policy changes on disposable income}

A. By income decile, \%, CPI indexation

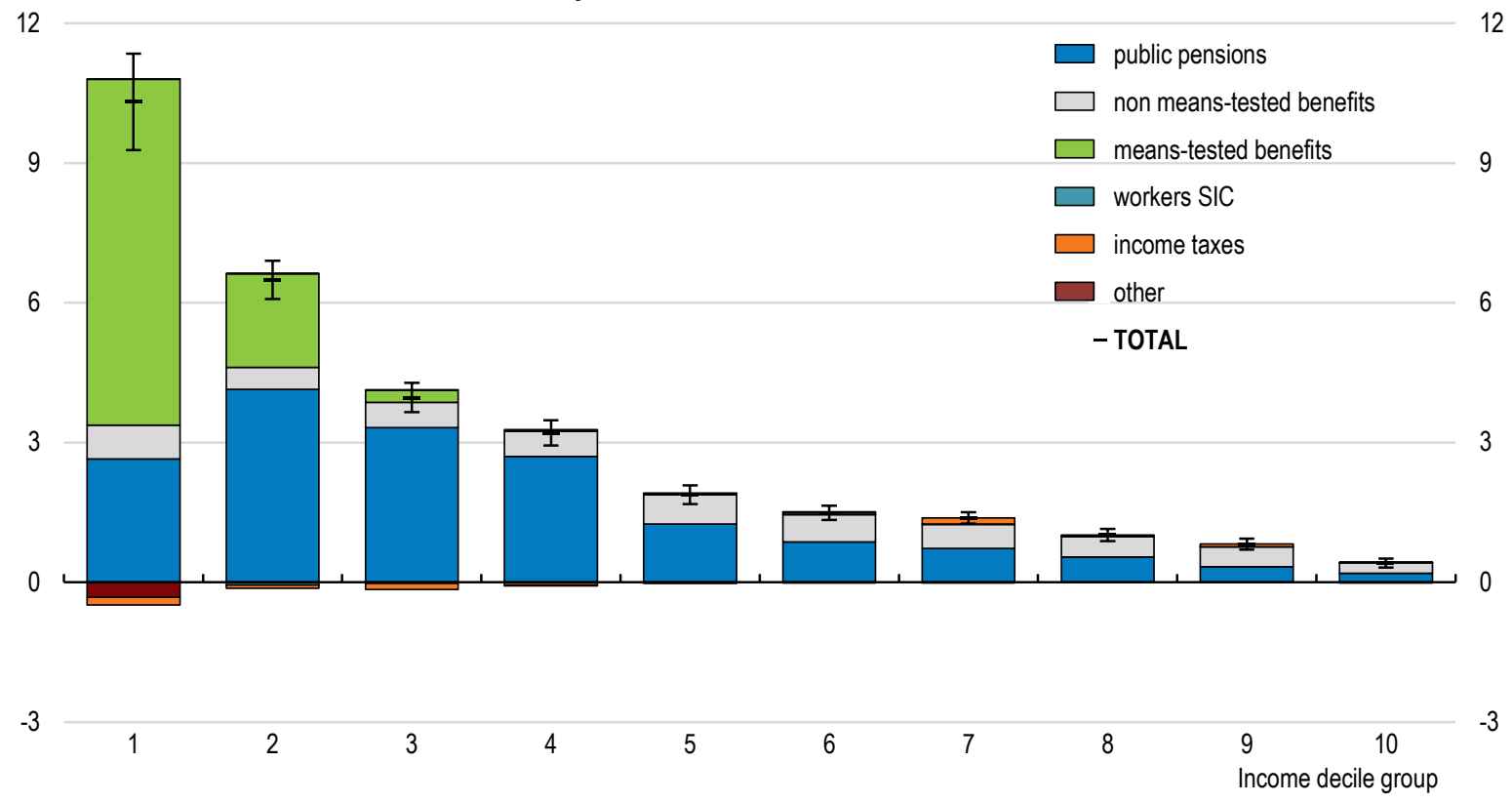

\section{B. By income decile, \%, MII indexation}

12

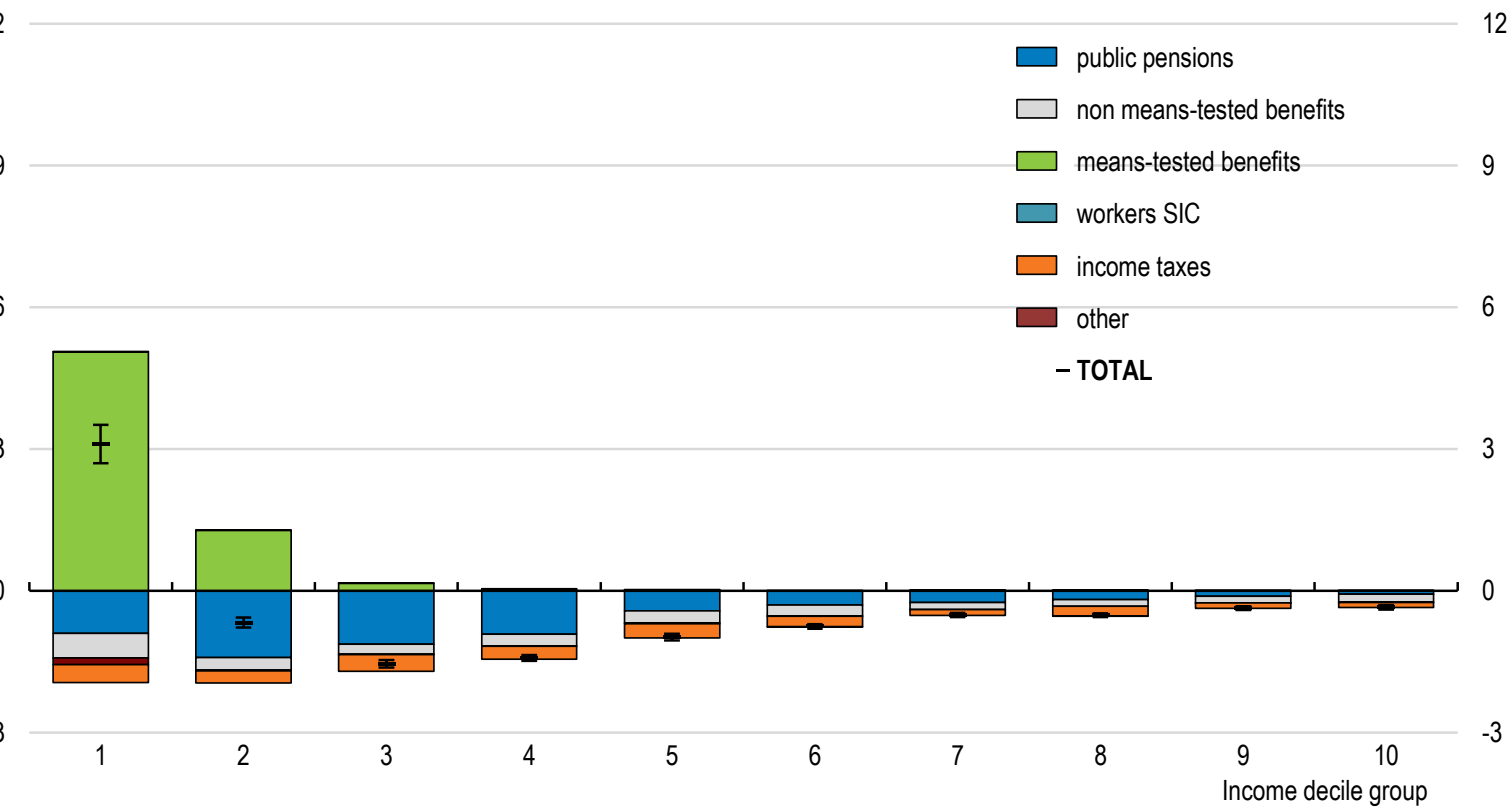

Note: The estimates are obtained by comparing household income distributions under 2015 and 2017 policies, with unchanged household characteristics. Monetary values of policy parameters have been adjusted with CPI in Panel A (baseline benchmark) and MII in Panel B (alternative benchmark). 95\% confidence intervals are shown for the total estimate.

Source: Authors' calculations based on EUROMOD and SILC. 
Figure 5. Estimated effects of recent policy changes on poverty and inequality

A. Relative change in poverty and income inequality

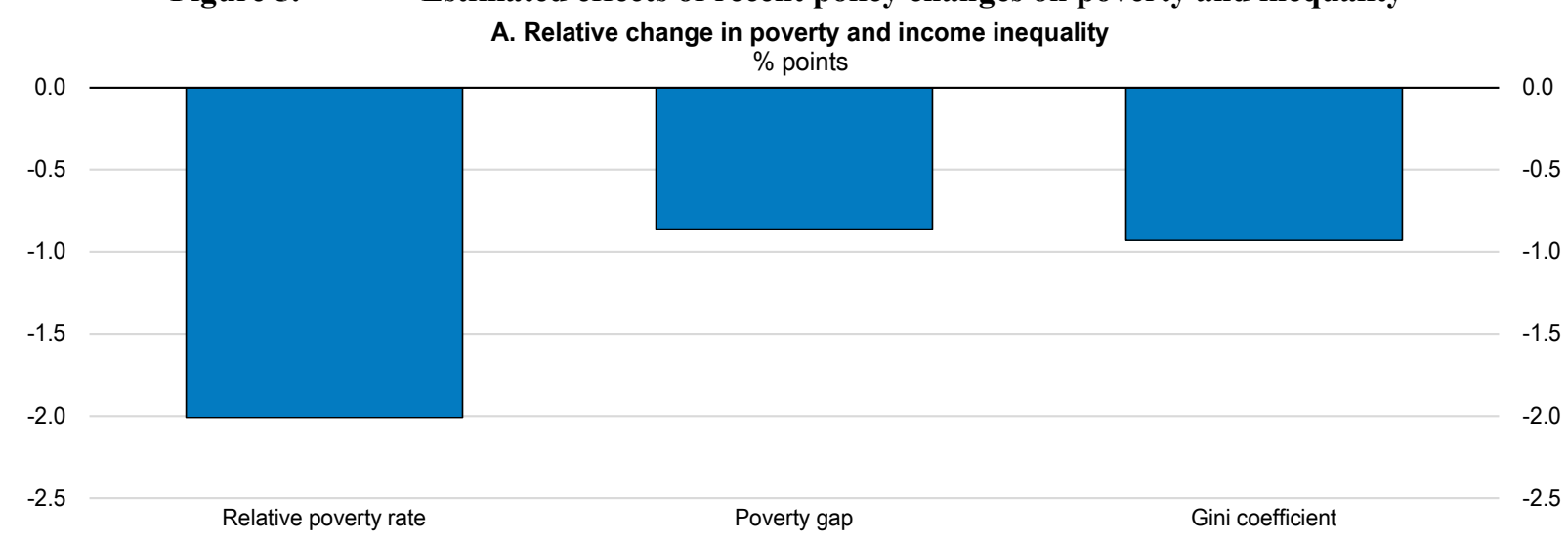

B. Impact on disposable income, by age group, $\%$

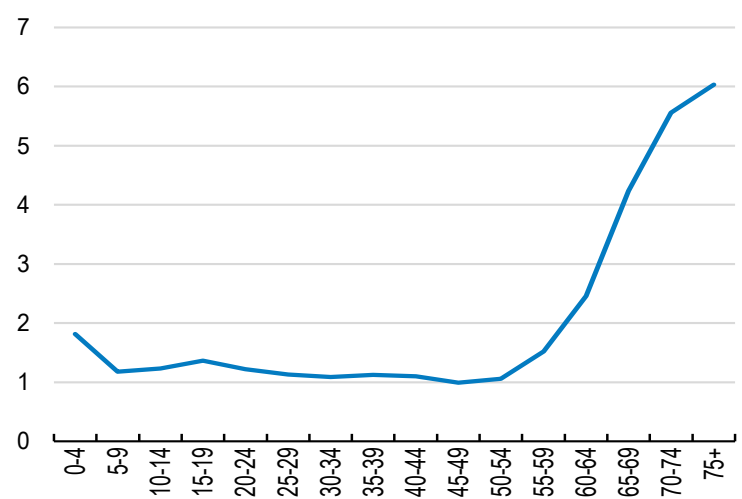

C. Relative change in poverty, by age group and household type, \% points

Note: The estimates are obtained by comparing household income distributions under 2015 and 2017 policies, with unchanged household characteristics. Monetary values of policy parameters have been adjusted with CPI. The poverty line is $60 \%$ of the median of equivalised household disposable income in the corresponding scenario (i.e. adjusted for changes in median income).

Source: Authors' calculations based on EUROMOD and SILC.

\section{Impact of selected 2017-18 tax-benefit reforms}

A range of measures aiming at reducing inequality and fighting poverty have been implemented after June 2017. Important changes, not least in terms of fiscal impact, include an increase in the income tax allowance, an increase of the child benefit and the parental allowance allocated to large families, and the extension of the latter to families with 3-6 children.

The income tax allowance was increased substantially in 2018 from EUR 170 to EUR 500 per month and progressively withdrawn for taxable incomes above EUR 1200 . The firstorder fiscal cost of the measure is estimated to be large, EUR 236 million on a yearly basis, accounting for around $15 \%$ of total personal income tax revenues. The measure is found to benefit more those in the middle of the income distribution (Figure 6, Panel A).

The personal income tax reform is estimated to have reduced poverty by 1.6 percentage point and the Gini coefficient by 0.8 percentage point (see Figure 6, Panel B), which is significant but is relatively less cost-efficient than other types of measures (see below). Work incentives are strengthened for low wage earners both at the intensive and the extensive margin (see Figure 6, Panel D, E, and F). Marginal effective tax rates are however higher for those in the higher end of the income distribution (i.e. those earning more than 
EUR 1200 per month Figure 6, Panel F). This is due to the combination of an increase of the non-taxable income and the introduction of progressivity in the income tax allowance.

The generosity of family benefits has been extended further with the increase in the child benefit to EUR 55 per month/child and in the parental allowance targeted to large families to EUR 300 per month, combined with its extension to families with 3-6 children. These measures are estimated to have increased the combined budget of the two instruments by around $40 \%$ (EUR 63 million per year). This is found to reduce the poverty rate by about 0.6 percentage point, with a negligible impact on the poverty gap and the Gini (Figure 7, Panel B). In the same vein, effects on work incentives are found to be marginal (Figure 7, Panel D to F). 
Figure 6. $\quad$ Estimated effects of the personal income tax reform

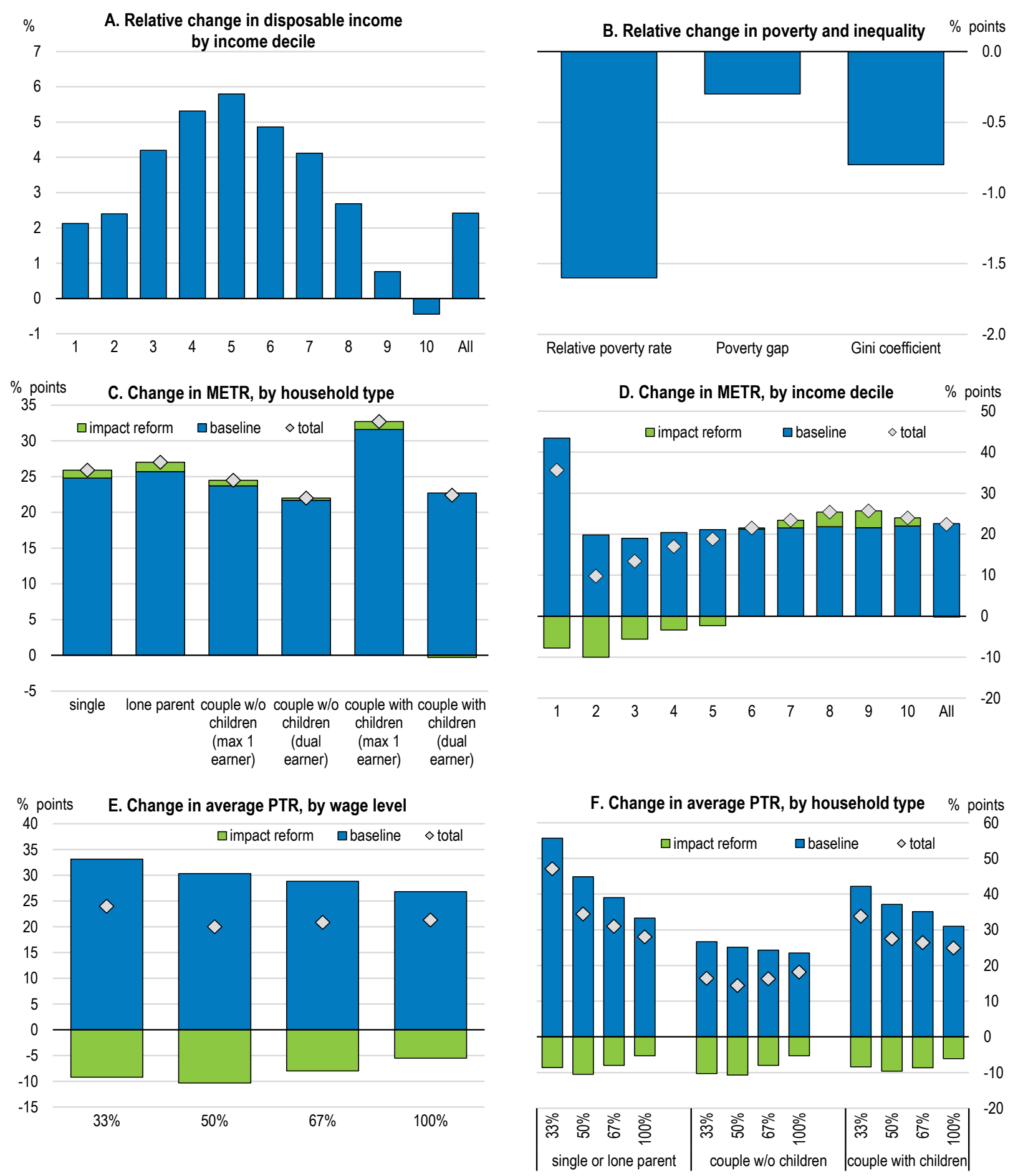

Note: The poverty line is $60 \%$ of the median of equivalised household disposable income in the baseline scenario. The participation rates are calculated for individuals out of the labour market. Children refer to persons younger than 18 and other household types (e.g. parents with children older than 18 or multi-generational families) are not included.

Source: Authors' calculations based on EUROMOD and SILC. 
Figure 7. Estimated effects of the family benefit reform

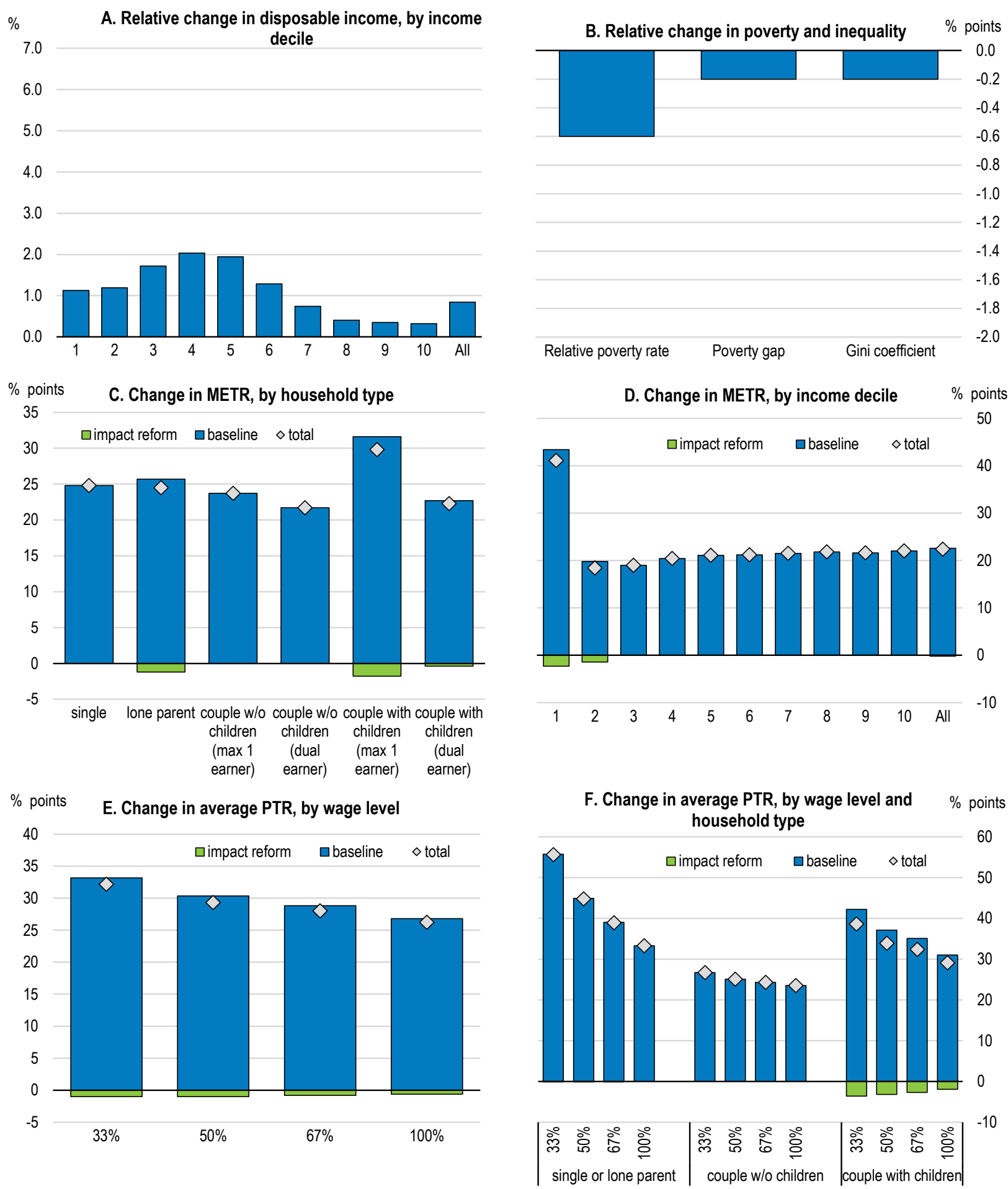

Note: The poverty line is $60 \%$ of the median of equivalised household disposable income in the baseline scenario. The participation rates are calculated for individuals out of the labour market. Children refer to persons younger than 18 and other household types (e.g. parents with children older than 18 or multi-generational families) are not included.

Source: Authors' calculations based on EUROMOD and SILC. 


\section{Impact of alternative measures}

\section{Reforming unemployment benefits}

The Estonian unemployment benefit system fails to adequately protect job seekers. Despite a two-tier unemployment support, the coverage of unemployment benefit system is relatively low, amounting to $50-55 \%$ of all registered unemployed and $30-38 \%$ of total unemployed (Figure 8). Young and low skilled workers, in particular those with nonstandard work contracts, face the highest risk of income loss and have a weak attachment to the social insurance system (Maquet et al., 2016).

Figure 8. Coverage of unemployment benefits

Share of monthly unemployment benefit recipients to registered unemployed, \%

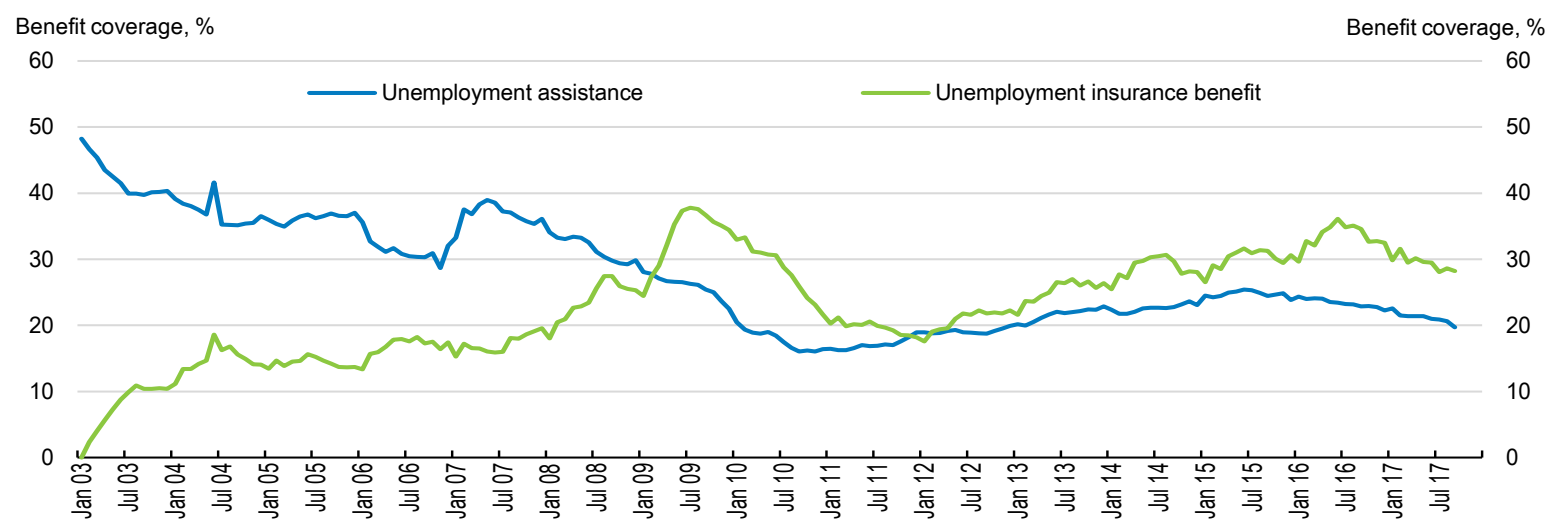

Note: Registered unemployed includes all persons registered for at least 1 day during the month; benefit recipients includes all persons entitled for at least 1 day during the month.

Source: Authors' calculations based on data from Estonian Unemployment Insurance Fund.

The low coverage of unemployment benefits is due to strict eligibility conditions in terms of contributions records, stricter than in most OECD countries. In particular, the unemployment assistance is subject to a minimum employment requirement and is meanstested unlike in most OECD countries. Furthermore, the base rates of unemployment assistance and the subsistence benefits - the social safety net of last resort - are very similar (EUR 148 vs. EUR 130 in 2017).

Further simulations assessed the potential impact of hypothetical reforms of the unemployment benefit system to improve its coverage and its generosity. The first scenario simulates the extension of the unemployment assistance benefit for all unemployed who are not eligible to unemployment insurance benefit. The second scenario increases the unemployment assistance benefit to around $40 \%$ of minimum wage (from around $30 \%$ in 2017).

Given the low number of unemployed in the reference year and the low level of the unemployment assistance benefit, fiscal and redistributive effects are modest in the first scenario (Figure 9). The impact is not significant in the second one (results not reported). The simulations provide a higher bound of cost estimates as it is assumed that all recipients remain unemployed and received the unemployment benefit over the simulation period. The simulations also show that the measure induces a substantial drop in the number of social assistance recipients and the cost of social assistance (-12\%) as entitlements become smaller and less people satisfy the means-test. Overall the fiscal impact is low $(0.1 \%$ of GDP). Combining both measures enhances positive distributional effects, which remain marginal though. 
Figure 9. $\quad$ Estimated effects of unemployment assistance scenario
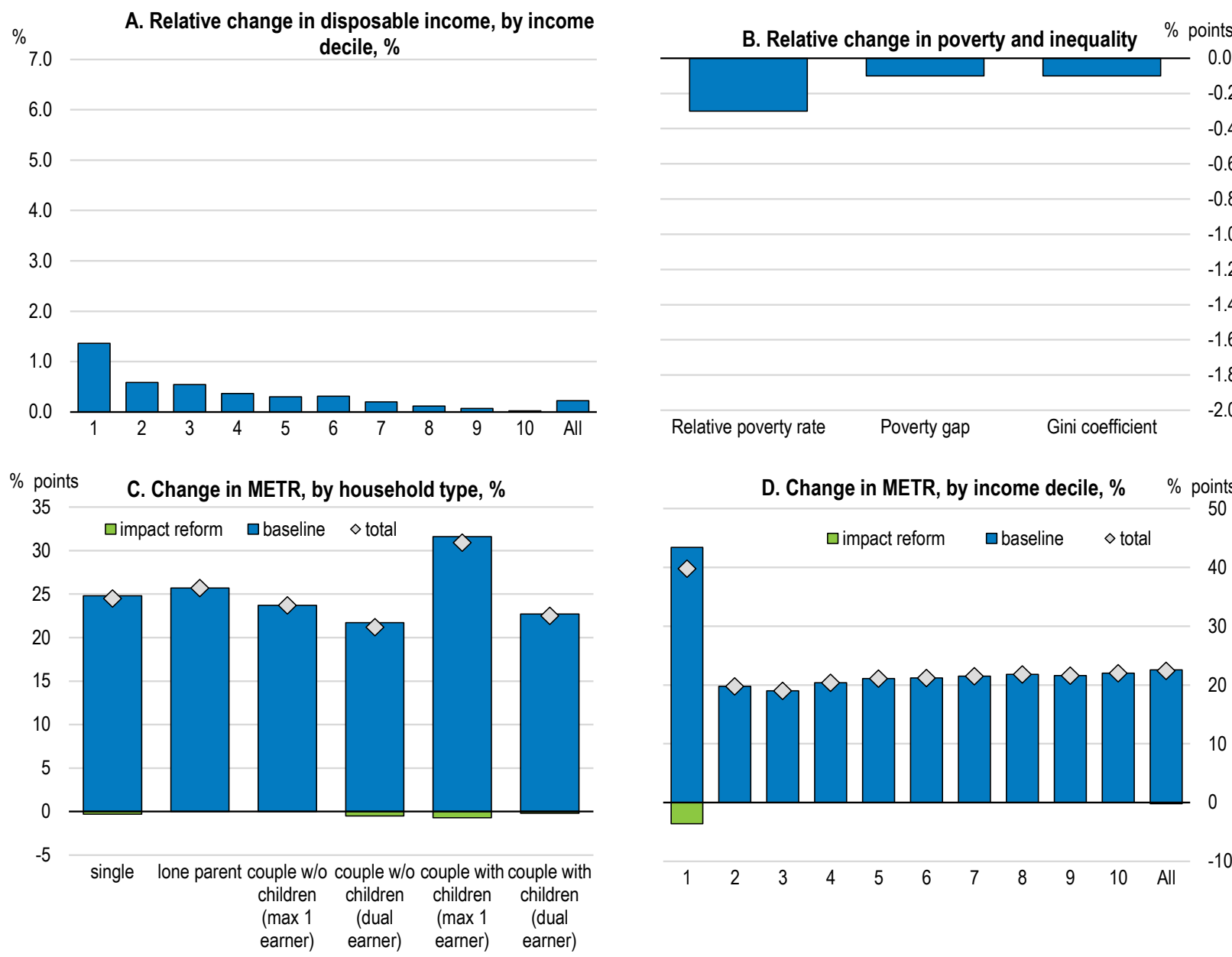

D. Change in METR, by income decile, $\% \quad \%$ points

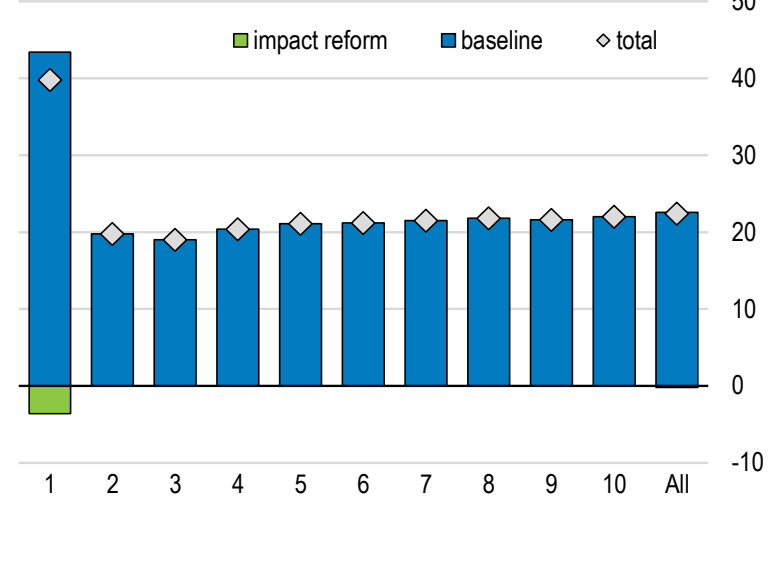

$\%$ points $\quad$ E. Change in average PTR, by wage level, $\%$
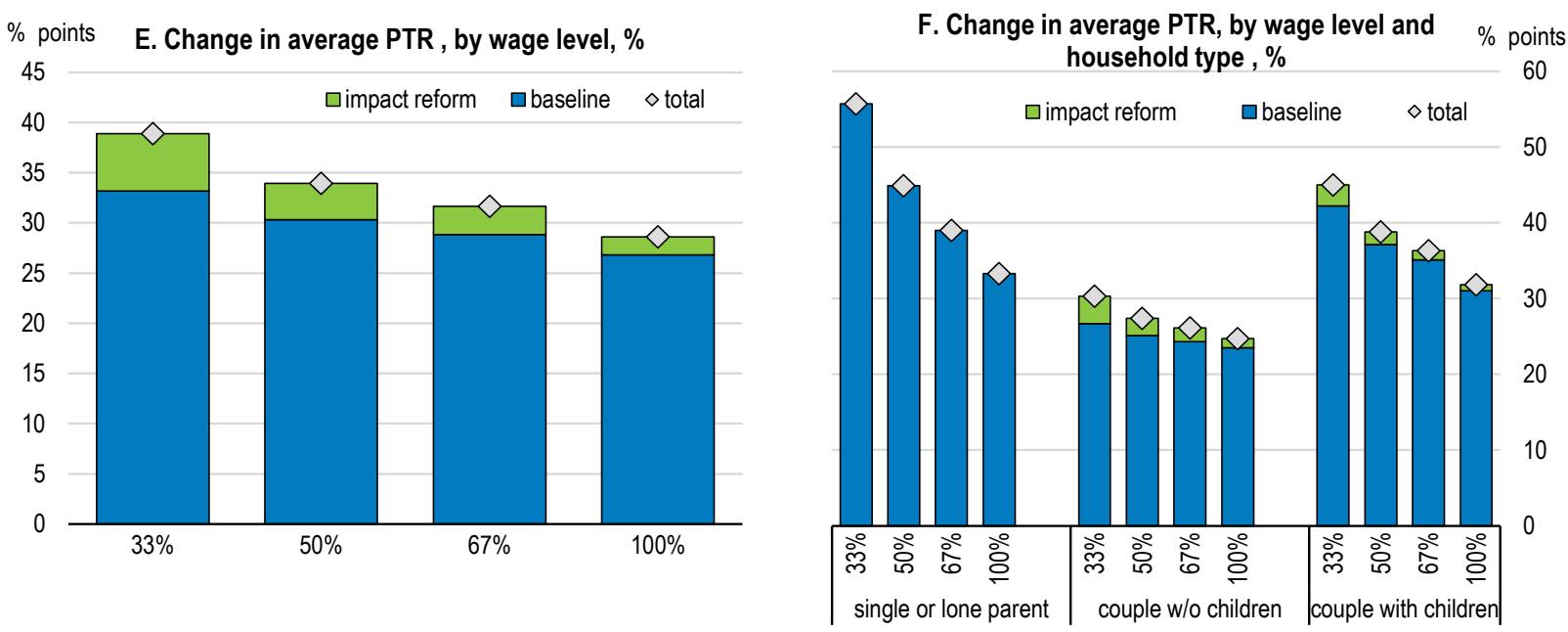

Note: The participation rates are calculated for individuals out of the labour market. Children refer to persons younger than 18 and other household types (e.g. parents with children older than 18 or multi-generational families) are not included.

Source: Authors' calculations based on EUROMOD and SILC. 


\section{Reforming social assistance}

Social assistance benefits, which provide last resort income for out-of-work individuals not eligible for unemployment benefits, do not sufficiently protect recipients against poverty. Despite a significant increase in 2016, the level of social assistance has not stepped up to a level that would minimise the risk of poverty. The guaranteed minimum income benefits stood between $16 \%$ and $34 \%$ of the median equivalised disposable income, substantially below relative poverty thresholds and the OECD average for households without children. Social assistance is also associated with low incentives to work as recipients face a withdrawal rate of $100 \%$ (i.e. for every additional euro earned, the benefit is reduced by EUR 1).

Three hypothetical scenarios of reforms improving the adequacy of the social safety net were simulated:

- The first scenario doubles the rate of subsistence benefits to reach the OECD average ( $40 \%$ of the median income)

- The second scenario halves the benefit withdrawal rate.

- The third scenario introduces income disregards (earnings up to $50 \%$ of the minimum wage are exempted from the benefit means-test)

The social assistance scenarios are associated with an estimated increase of public spending between $0.1 \%$ and $0.8 \%$ of GDP. Increasing the rate of the subsistence benefit induces a relaxation of the eligibility criteria. As a result, the number of benefit recipients increases significantly in all scenarios (by $200 \%$ in the first, $350 \%$ in the second and $45 \%$ in the third scenario). While in the baseline scenario, the recipients were only located in the bottom income decile group, they can now be found up to the fifth decile group.

Simulated measures are found to have large distributional effects. Doubling the benefit rate reduces the relative poverty rate by almost 6 percentage points and the poverty gap by around 2.5 percentage points. The measure simulated in the second scenario benefits more poor households with some income and has thus a lower impact on poverty (Figure 10, Panel B). Finally, the introduction of income disregards simulated in the third scenario has a positive but small poverty-reducing impact, as it induces a lower level of spending and it also affects those with alternative revenue sources.

While the third scenario is found to have a marginal effect on work incentives, the first two are estimated to increase significantly both marginal effective tax rates and participation tax rates at the bottom of the income distribution. Doubling the level of the subsistence benefit is estimated to increase METR by 32 percentage points on average for the bottom three decile groups (Figure 10, Panel D) as now more households are eligible for the benefit and hence face a very high METR. PTR for those earning less than $100 \%$ of the average wage exceed $40 \%$ after the reform (Figure 10, Panel F). Halving the benefit withdrawal rate increases the number of eligible households even more, however, the increase in METR is rather muted on average for the first decile because the current benefit recipients would see their METRs significantly reduced. 
Figure 10. Estimated effects of social assistance scenarios
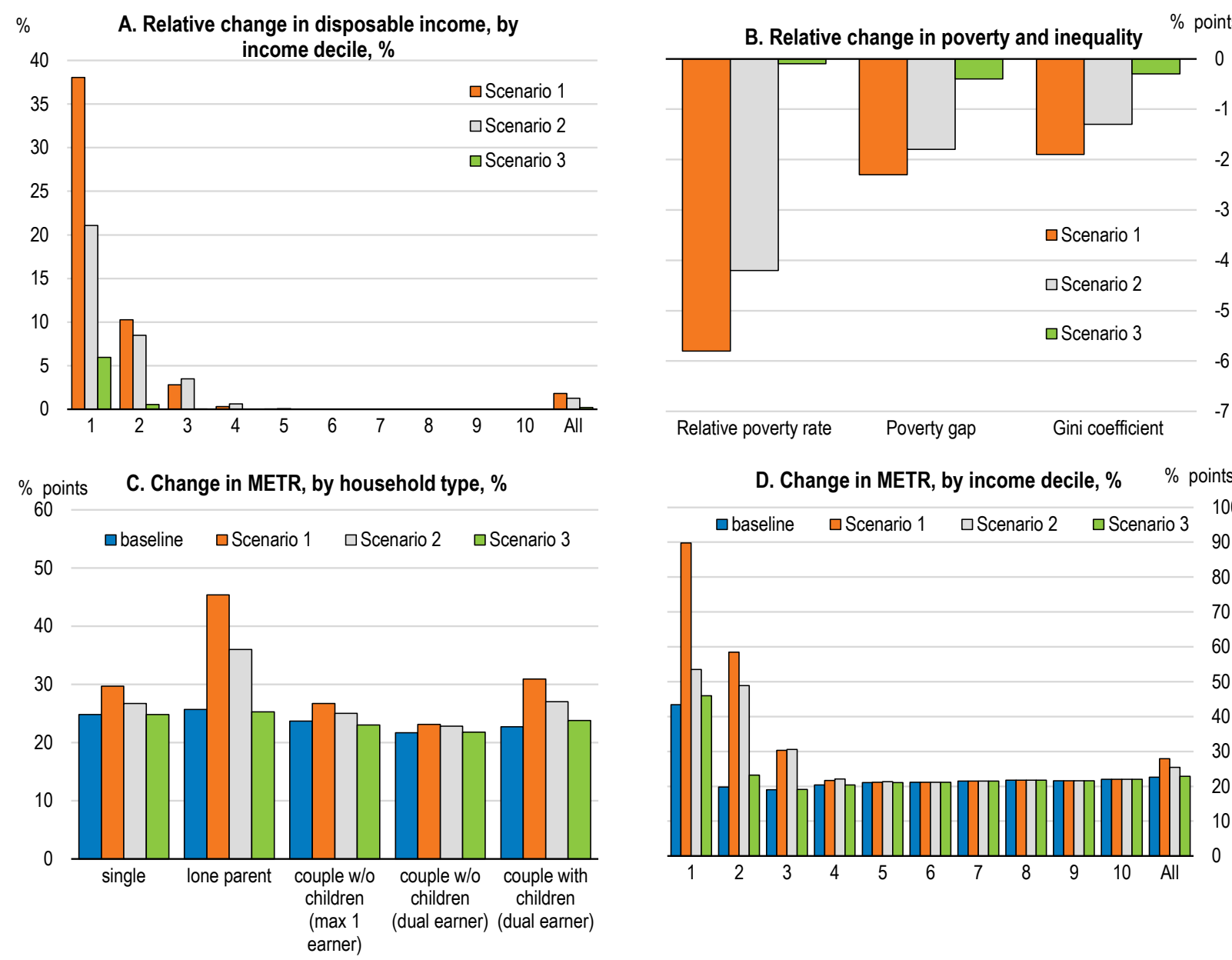

D. Change in METR, by income decile, \% \% points
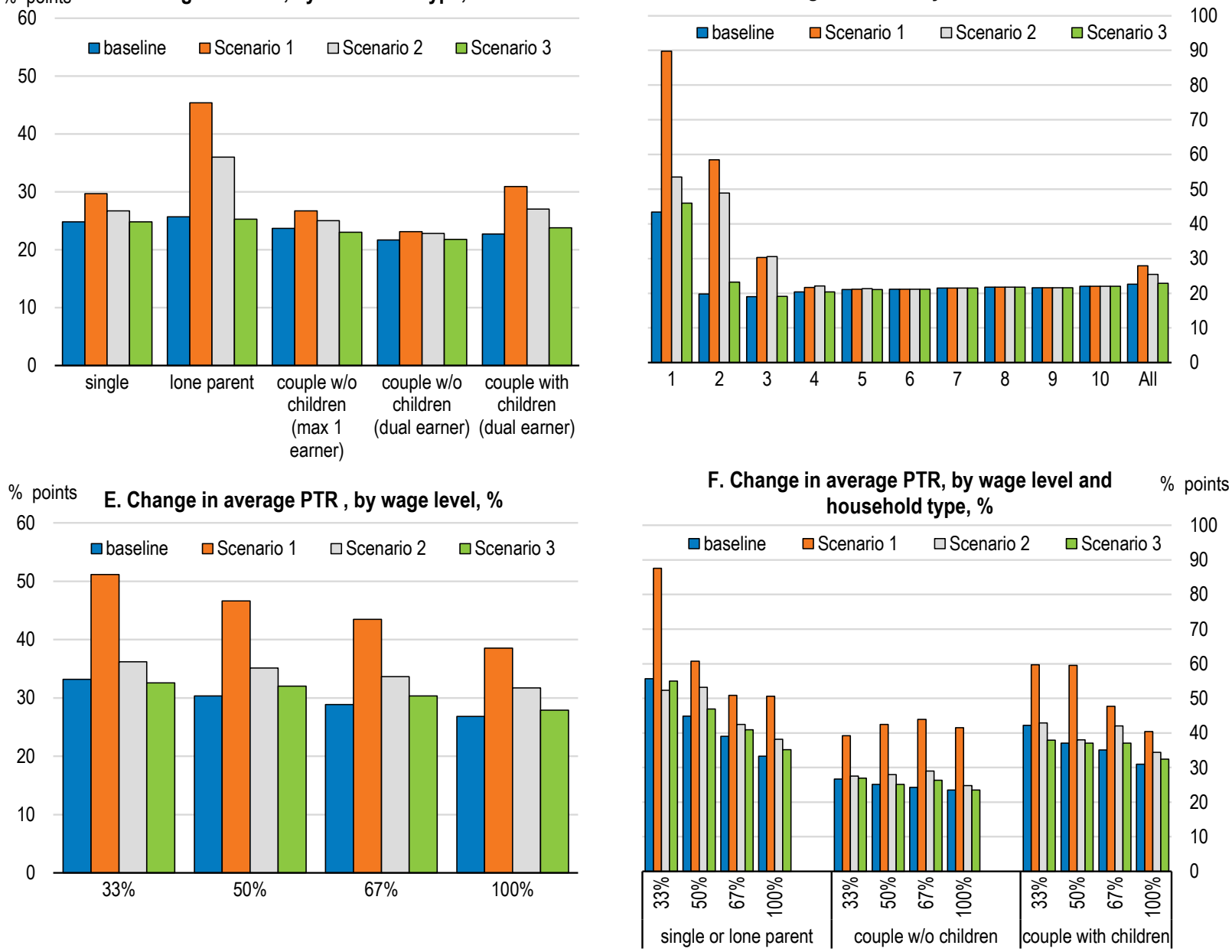

Note: scenario 1: the rate of subsistence benefits is doubled, scenario 2: the benefit withdrawal rate is halved, scenario 3: income disregards up to $50 \%$ of the minimum wage are introduced. The participation rates are calculated for individuals out of the labour market. Children refer to persons younger than 18 and other household types (e.g. parents with children older than 18 or multi-generational families) are not included. Source: Authors' calculations based on EUROMOD and SILC. 


\section{Comparing the impact of simulated measures}

\section{Relative impact on poverty and inequality}

To facilitate a comparison of inequality and poverty alleviation across the scenarios, poverty and inequality reduction per unit cost is calculated by dividing the change in percentage points of the poverty index and the Gini coefficient by the estimated fiscal cost of the measure (Figure 11). Results suggest that the hypothetical reforms of the social assistance are the most cost-efficient in reducing poverty while the 2018 reforms of the personal income tax and family benefits are the least cost-efficient (Figure 12). Interestingly, introducing income disregards in the social assistance benefit system induces a relatively small budgetary cost but has a relatively large progressive impact.

It should be noted however that only first-order effects are simulated here. By cutting labour taxation, the personal income tax reform would boost labour supply and increase tax revenues. At the same time, as shown above, raising the generosity of social assistance reduces incentives to work, thereby increases the number of benefit recipient and spending in social programmes.

Also, the redistributive impact of the financing of these measures is not taken account in the model. Total impact will crucially depend on whether the measures are financed by tax increases, spending cuts, or higher deficit, as well on the policy mix, some taxes and cuts being more harmful to growth and inclusiveness than others (Fournier and Johansson, 2016). Taking into account these second-round and financing effects is out of the scope of this paper and would require using microsimulation results in macro-econometric models as done for instance in Barrios et al. (2016).

\section{Figure 11. Estimated net impact on public spending}

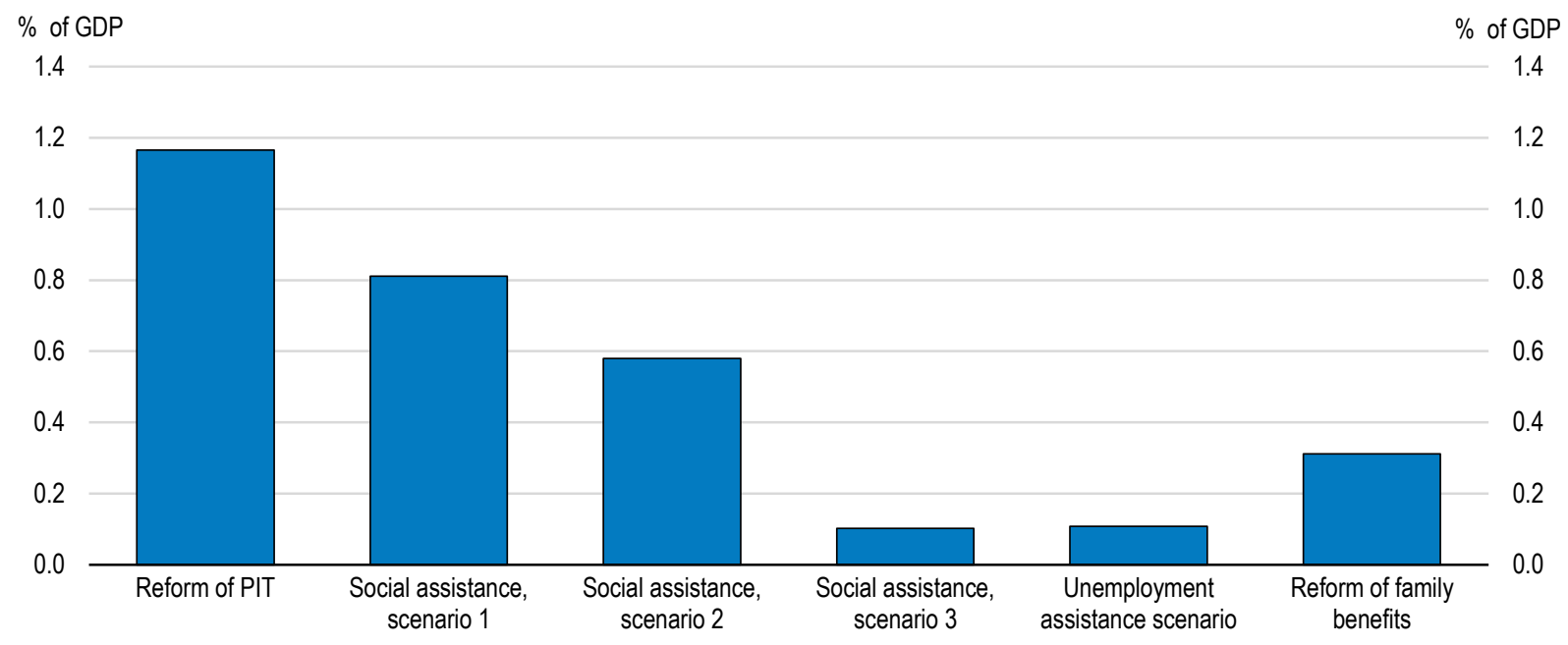

Note: The impact on public finances is measured as the sum of net changes in spending induced by the simulated measures minus the net impact of simulated measures on tax revenues.

Source: Authors' calculations based on EUROMOD and SILC. 
Figure 12. Estimated impact on poverty and inequality by EUR billion cost

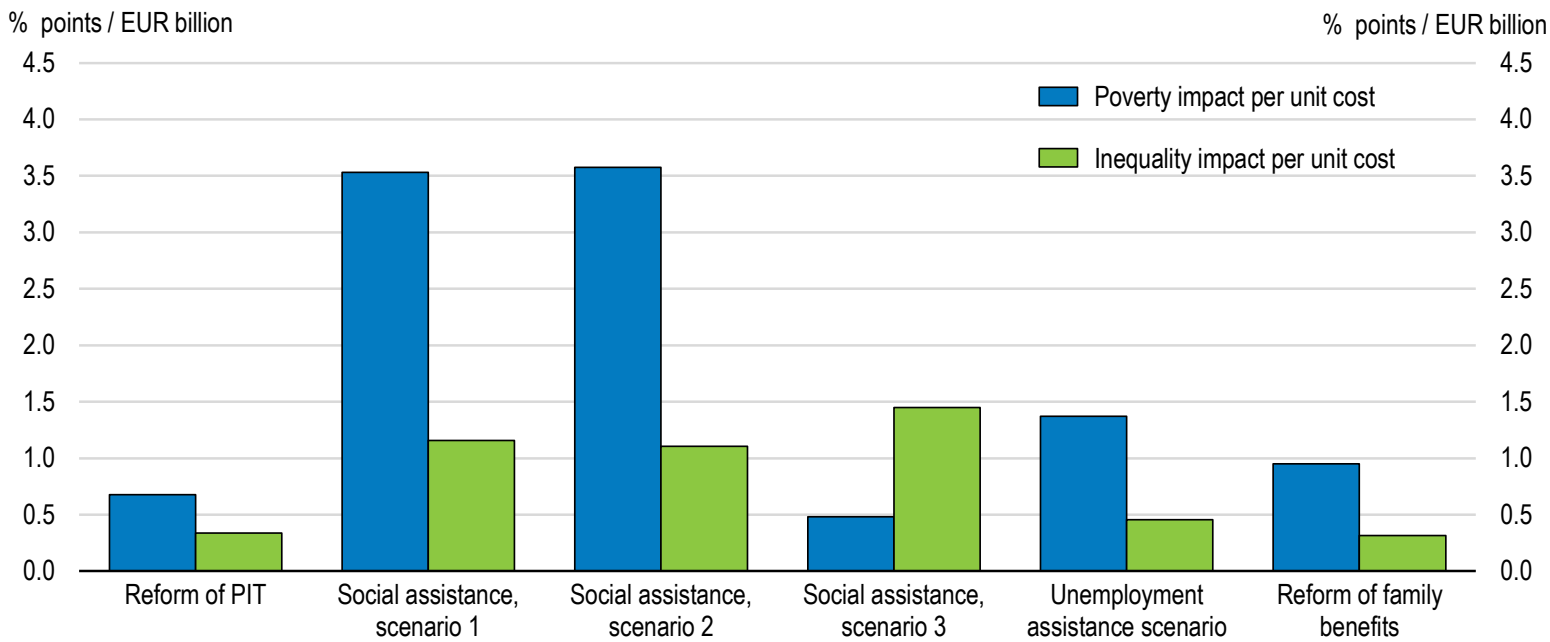

Note: The impact is measured by the changes in poverty rate and Gini coefficient respectively, in percentage points divided by the impact on public finances in EUR billion.

Source: Authors' calculations based on EUROMOD and SILC.

\section{Trade-off between work incentives and redistributive effects}

The simulations points to the traditional trade-off between increasing social protection and preserving high work incentives. Measures with the highest poverty reducing effects (also when unit cost is taken into account) are also those which tend to reduce work incentives. While the reforms of social assistance tend to increase effective taxation of work (the first and the second scenarios), other measures tend to have limited impacts overall both at the intensive and the extensive margins (Figure 13, Panel A and D).

Effects on marginal effective tax rates or participation tax rates tend to vary significantly across the income distribution (Figure 13, Panel B). The lower part of the income distribution appears to be the most affected by the simulated measures. In particular, improving the generosity of social assistance increases significantly the effective taxation of labour at the bottom of the income distribution and for groups of households that face already high disincentives to work (lone parents).

Work incentives in the median or the upper part of the income distribution are not significantly impacted by the simulated measures, except the 2018 reform of the personal income tax. The latter reduces marginal effective tax rates for low-income earners $(-8 \mathrm{pp}$ for the bottom three decile groups) while it increases them for high-income earners $(+3 p p$ for the upper three decile groups). At the same time, the PIT reform increases incentives at the extensive margin as it reduces the participation tax rates at all wage levels and across the income distribution. 
Figure 13. Trade-off between poverty reduction and increases in work disincentives

\section{A. Poverty reduction and METR change}

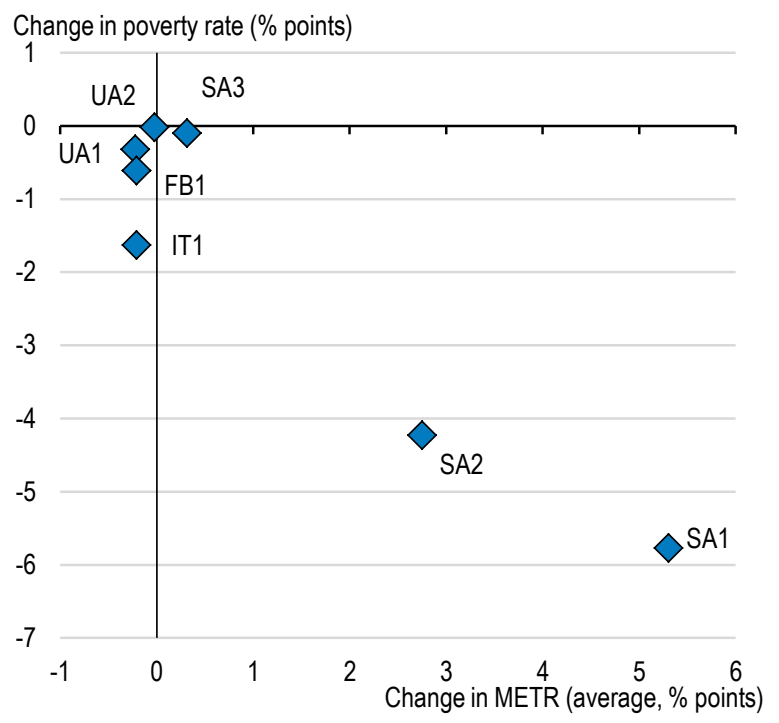

C. Poverty reduction per unit cost and METR change

Poverty reduction per unit cost $(\%$ points/EUR

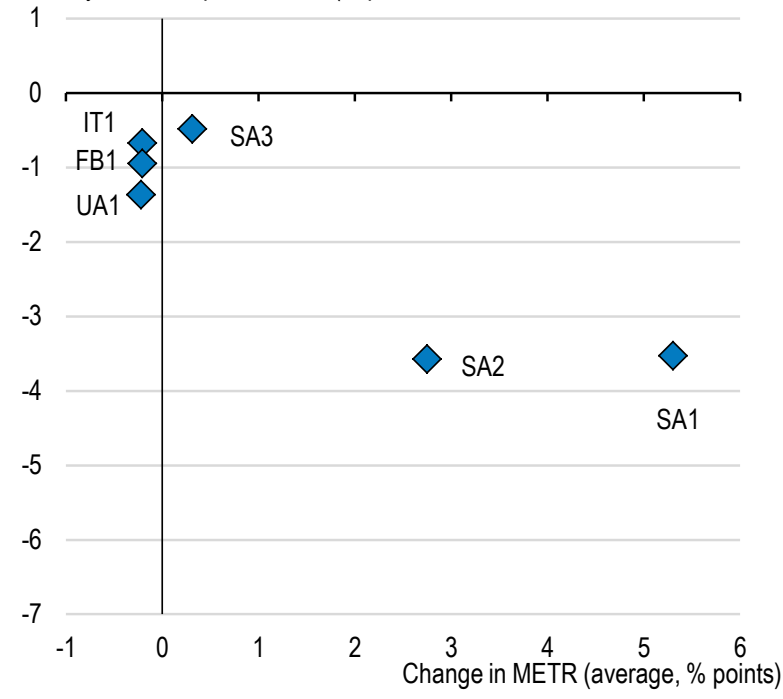

B. Poverty reduction and METR change for low income earners

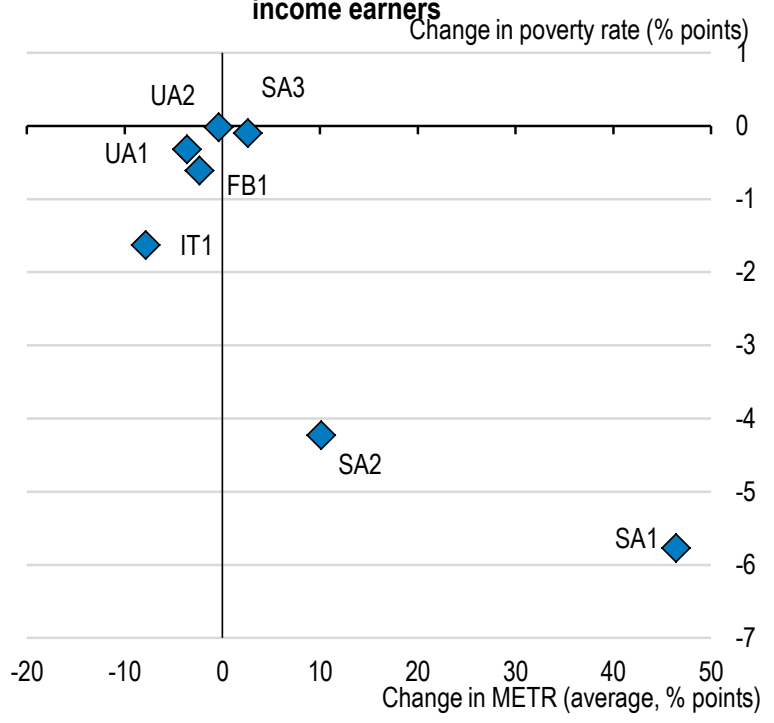

D. Poverty reduction and PTR change at $33 \%$ of average waghange in poverty rate (\% points)

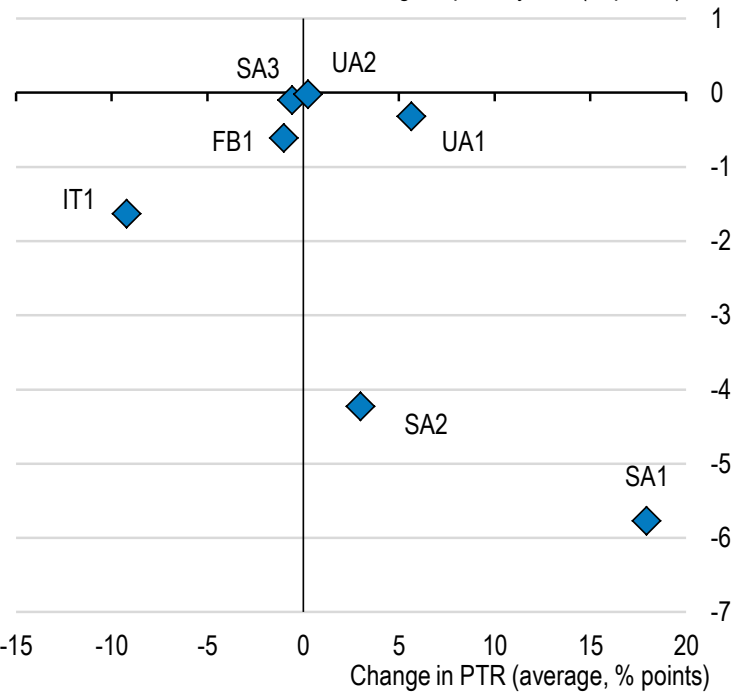

Note: IT1 refers to the PIT reform, FB1 refers to the family benefit reform, UA1 and UA2 refer to the unemployment scenario 1 and 2 respectively, SA1, SA2 and SA3 refer to the social assistance scenario 1, 2, and 3 respectively. The participation rates are calculated for individuals out of the labour market. Panel B shows the change in average METR for the first income decile group.

Source: Authors' calculations based on EUROMOD and SILC.

\section{Conclusion}

This paper analyses actual and hypothetical reforms of the tax and benefit system aiming at improving adequacy of social protection while preserving incentives to participate in the labour market in Estonia. Impact of measures, including the 2018 changes in the personal income taxation and family benefits, and of alternative measures affecting the 
unemployment and social assistance schemes are simulated using EUROMOD, a taxbenefit micro-simulation model.

The simulations found a progressive impact of reforms implemented between 2015 and 2017, not least due to increases in means-tested benefits and nominal public pensions. By contrast, the personal income tax reform in 2018, which increased the personal income tax allowance, is found to benefit the most middle-income earners while strengthening incentives to work at low wage levels. Such a measure reduces poverty and inequality and stimulates labour supply, but is not cost-efficient compared to other policy actions given its high fiscal cost.

Increasing the level of subsistence benefits to the OECD average would have strong progressive effects on household incomes at the bottom of the distribution and would reduce poverty significantly. However, such a measure increases effective taxation of labour incomes, especially at low wage level, and the number of benefit recipients. Reducing the withdrawal rate of social assistance or introducing income disregards induces smaller adverse effects (i.e. lower budgetary costs and effective taxation of work at both the intensive and extensive margins). Further analyses of combined reforms are promising candidates for future work.

The simulations presented in this paper estimate first order effects of policy measures and assume full take-up rates of benefits and full tax compliance. They do not take into account behavioural changes induced by the measures, as regards employment or tax fraud. As discussed in the paper, evaluating the impact of financing of the measures is out of the scope of this paper and would have to be considered in future research.

\section{BIBLIOGRAPHY}

Bargain, O., and T. Callan (2010), "Analysing the effects of tax-benefit reforms on income distribution: A decomposition approach", Journal of Economic Inequality 8(1), 1-21.

Barrios, S., Dolls, M., Maftei, A., Peichl, Riscado, S., Varga, J. and Wittneben, C. (2016), "Dynamic scoring of tax reforms in the European Union", JRC Working Papers on Taxation and Structural Reforms, No 3/2016, European Commission, Joint Research Centre, Seville.

Causa, O. and M. Hermansen (2017), "Income redistribution through taxes and transfers across OECD countries", OECD Economics Department Working Papers, No. 1453, OECD Publishing, Paris, https://doi.org/10.1787/bc7569c6-en

De Agostini, P., A. Paulus, and I. Tasseva (2015), "The effect of tax-benefit changes on the income distribution in 2008-2014", EUROMOD Working Paper EM11/15, Colchester, University of Essex.

De Agostini, P., A. Paulus, and I. Tasseva (2016), "The effect of tax-benefit changes on the income distribution in 2008-2015", EUROMOD Working Paper EM6/16, Colchester, University of Essex.

Foster, J., J. Greer, and E. Thorbecke (1984), “A class of decomposable poverty measures”, Econometrica, Vol 52(3), 761-766. 
Fournier, J. and Å. Johansson (2016), "The Effect of the Size and the Mix of Public Spending on Growth and Inequality", OECD Economics Department Working Papers, No. 1344, OECD Publishing, Paris. http://dx.doi.org/10.1787/f99f6b36-en.

Immervoll, H. (2005), "Falling up the stairs: The effects of 'bracket creep' on household incomes", Review of Income and Wealth, 51(1), 37-62.

Langenbucher, K. (2015), "How Demanding are Eligibility Criteria for Unemployment Benefits, Quantitative Indicators for OECD and EU Countries", OECD Social, Employment and Migration Working Papers, No. 166, OECD Publishing, Paris, http://dx.doi.org/10.1787/5jrxtk1zw8f2-en.

Maquet, I., V. Maestri, and C. Thévenot (2016), “The coverage rate of income support measures in the EU: measurement and challenges", European Commission.

Masso, M., C. Leppik, A. Paulus, and M. Piirits (2017), EUROMOD Country Report: Estonia 20142017, Colchester: University of Essex.

Masso, M., A. Paulus, M. Piirits, H. Biin, K. Melesk (2018), EUROMOD Country Report: Estonia 2015 2017, Colchester: University of Essex.

Navicke, J., S. Avram and L. Demmou (2016), "The effects of reform scenarios for unemployment benefits and social assistance on financial incentives to work and poverty in Lithuania", OECD Economics Department Working Papers, No. 1310, OECD Publishing, Paris. http://dx.doi.org/10.1787/5jlv2jmtmsmr-en.

OECD (2008), "Declaring Work or Staying Underground: Informal Employment in Seven OECD Countries", Employment Outlook 2008, OECD Publishing.

OECD (2012), Economic Surveys: Estonia, OECD Publishing, Paris. http://dx.doi.org/10.1787/22212302.

OECD (2017), Economic Surveys: Estonia, OECD Publishing, Paris. http://dx.doi.org/10.1787/eco_surveys-est-2017-en.

Paulus, A., and I. Tasseva (2018), "Europe through the crisis: Discretionary policy changes and automatic stabilisers", EUROMOD Working Paper EM16/18, Colchester, University of Essex.

Paulus, A., H. Sutherland, and I. Tasseva (2019), "Indexing out of poverty? Fiscal drag and benefit erosion in cross-national perspective", Review of Income and Wealth, forthcoming. http://doi.org/10.1111/roiw.12413.

Sutherland H. and F. Figari (2013), "EUROMOD: the European Union tax-benefit microsimulation model", International Journal of Microsimulation, 6(1).

Tatsiramos (2009), "Unemployment Insurance in Europe: Unemployment Duration and Subsequent Employment Stability", Journal of the European Economic Association, Vol. 7(6).

Wulfgram and Fervers (2013). "Unemployment and Subsequent Employment Stability: Does Labour Market Policy Matter?", IZA Discussion Paper, No. 7193. 


\section{Annex 1. \\ Out-of-work benefits in Estonia (2017)}

\section{Unemployment benefits}

When becoming unemployed, people can get financial support in the form of unemployment insurance benefit (UIB) or unemployment allowance (UA). Both schemes require a person to be officially registered as unemployed, which excludes people under 16, those who have reached the legal retirement age or are in receipt of early retirement pension, students in full-time education as well as those registered as self-employed. Eligibility conditions are relatively strict and include active job search, also during participation in ALMPs (Langenbucher, 2015). Meetings with the job counsellor must be attended at least once a month. Sanctions for failures to comply with such requirements are in theory comparatively severe: claimants can have their claims terminated if they refuse job offers or participation in ALMPs.

\section{Unemployment insurance benefit (UIB)}

The unemployment insurance benefit (töötuskindlustushüvitis) is a contributory benefit financed from compulsory unemployment insurance contributions paid by both employers (one third) and employees (two thirds). Since its introduction in 2002, the contribution rates have been set in the range of $0.3-1.4 \%$ for employers and $0.6-2.8 \%$ for employees in a pro-cyclical manner depending on the unemployment level.

To qualify for the benefit, a person must be registered as unemployed, actively look for a job and have paid unemployment insurance contributions for at least 12 months during the previous 36 months prior to registering as unemployed. Only involuntarily unemployed can apply - people who left their job voluntarily, in a mutual agreement with the employer, or lost their job due to inadequate work performance or misconduct are not eligible.

UIB entitlement is linked to individual earnings, capped at 3 times the national average wage, with a replacement rate of 50\% in the first 100 days and $40 \%$ in the remaining period. Since 2009 , there is also a minimum level applying to the benefit amount, guaranteeing that the entitlement is no smaller than $50 \%$ of minimum wage of the previous year (EUR 215 in 2017, 18\% of the average wage). The maximum duration of the benefit depends on the contribution history: 180 days for less than 5 years of contribution payments, 270 days for 5-10 years of contributions and 360 days for more than 10 years of contributions.

\section{Unemployment allowance (UA)}

The unemployment allowance (tö̈tutoetus) is provided to those who are not eligible to the UIB, under the conditions that the job seeker have worked (or studied) at least 180 days during the previous 12 months prior to registering as unemployed. The UA is a flat rate non-taxable monthly payment allocated for a maximum of 270 days with some exemptions for those close to legal retirement age (around EUR 150 in $2017,12 \%$ of the average wage). Since 2013 , the rate of benefit cannot be set lower than $35 \%$ of minimum wage of the previous year. The benefit is formally means-tested and withdrawn to those earning more than the benefit rate. 


\section{Social assistance}

Subsistence benefit (toimetulekutoetus) is the most generic means-tested benefit and a primary form of social assistance, providing households with a minimum guaranteed income net of housing costs. It has to be claimed on a monthly basis without limit on duration. The main eligibility criterion is based on household income, but local municipalities are free to impose job search requirements such as registering as unemployed, and can withdraw benefits if job offers are refused, or if the claimant person or household is deemed to have sufficient assets to support themselves.

The base rate (subsistence level) is supposed to correspond to the minimum expenses on goods and services needed to satisfy primary needs. The base entitlement is topped up by actual housing costs per 'norm space', subject to maximum limits set by each local government. The maximum household entitlement before taking housing costs into account is calculated as the base rate (EUR 130 in 2017) times the household equivalence scale, assigning 1 to the head and each child (aged under 18), and 0.8 to every other adult member. The means-test is based on household net income with some income disregards (other means-tested benefits). The base entitlement together with the housing component is reduced by income included in the means-test one-to-one (i.e. 100\% withdrawal rate) from the first euro. The final entitlement includes a small (non means-tested) supplement (15 euro/month) for single adult households with one or more dependents younger than 18 .

Needs-based family benefit (vajaduspõhine peretoetus), which was introduced in July 2013, provides a monthly supplement to families with children (EUR 45 and EUR 90 for families with more than one child). The benefit must be renewed every three months. To qualify, a family must be receiving the child benefit, and satisfy a means-test or have received the subsistence benefit in the previous month. The meanstest relies on the same income concept as is used for the subsistence benefit, but refers to average household net income in the previous 3 months. Similar to the subsistence benefit, the income threshold is adjusted with a household equivalence scale, but the latter differs from the one used for the subsistence benefit. Unlike the subsistence benefit and similar to the unemployment allowance, the needs-based family benefit is withdrawn all at once when family income exceeds the income threshold set at the relative poverty line published in the previous year ( $60 \%$ of the median household equalised disposable income two years ago).

An allowance for pensioners living alone (üksi elava pensionäri toetus) has been introduced in 2017. This is an annual payment to persons in the retirement age, whose net state pension is below a certain threshold, living alone or only with dependent children. The allowance amounts to EUR 115 euro (EUR 10 per month).

Table 3. Key parameters of unemployment and social assistance benefits

\begin{tabular}{lrrrr}
\hline & EUR/month & $\begin{array}{l}2011 \\
\% \text { of minimum wage }\end{array}$ & EUR/month & $\begin{array}{c}2017 \\
\% \text { of minimum wage }\end{array}$ \\
\hline $\begin{array}{l}\text { Unemployment insurance } \\
\text { benefit (minimum) }\end{array}$ & 139 & 50 & 215 & 45.7 \\
$\begin{array}{l}\text { Unemployment assistance } \\
\text { Subsistence benefit (minimum) }\end{array}$ & 64 & 23.1 & 148 & 31.4 \\
$\begin{array}{l}\text { Subsistence benefit average } \\
\text { payment }\end{array}$ & 77 & 27.6 & 130 & 27.7 \\
$\begin{array}{l}\text { Needs-based family benefit } \\
\text { (one child) }\end{array}$ & 147 & 52.9 & $213^{*}$ & $49.5^{*}$ \\
$\begin{array}{l}\text { Pensioner's living alone } \\
\text { allowance }\end{array}$ & - & - & 45 & 9.6 \\
\hline
\end{tabular}

1. Average among successful applications (with or without housing component). * refer to 2016 numbers. Source: National legislation, Statistics Estonia, Unemployment Insurance Fund, own calculations 